\title{
THROWING POWER IN CHROMIUM PLATING
}

\author{
By H. L. Farber ${ }^{1}$ and W. Blum
}

\section{ABSTRACT}

During recent years chromium plating has come into extensive use in spite of the fact that it is very difficult to deposit chromium in recesses of irregularly shaped articles. General principles show that in the chromic acid baths used for plating there is little hope of radically improving the "throwing power." The purpose of this investigation was to define those operating conditions which yield the highest throwing power, which at best is poor.

The ratio of the weights of metal deposited on two cathodes, one of which is twice as far from a gauze anode as the other, gives a quantitative measure of throwing power. If, under these conditions, as is invariably true in chromium plating, this metal ratio is greater than $2: 1$, the throwing power is negative. The best throwing power obtained was -13 per cent. Under less favorable conditions it was - 100 per cent or still poorer.

The conditions found to yield the best throwing power are $(a)$ a high temperature such as $55^{\circ}$ C. $\left(131^{\circ} \mathrm{F}.\right)$; (b) a high current density such as $35 \mathrm{amp} . / \mathrm{dm} .2^{2}$ (325 amp./ft. ${ }^{2}$ ); (c) a low concentration of chromic acid such as 150 to $250 \mathrm{~g} / \mathrm{L}$ (20 to $33 \mathrm{oz} . / \mathrm{gal}$.); and $(d)$ a low sulphate content, for example, $\frac{\mathrm{CrO}_{3}}{\mathrm{SO}_{4}}=200$. These conditions usually require a potential of over 6 volts. If this is not available, fair throwing power can be obtained in a more concentrated solution with a lower temperature and current density.

The numerical results for throwing power are approximately parallel to the covering power, as measured with copper cathodes bent at right angles.

\section{CONTENTS}

I. Introduction

II. Historical

III. Principles involved

1. Throwing power

(a) Definitions

(b) Factors involved

(1) Cathode polarization... 30

(2) Conductivity

(3) Cathode efficiency 32

2. Plating range

3. Covering power 33

IV. Methods of regulating the primary current distribution

1. Use of concentric or parallel anodes and cathodes......- 34

2. Increasing the distance between the anodes and cathodes.- $\quad 35$

3. Use of adjacent conductors.... 35

4. Use of nonmetallic shields

V. Methods of study 36

1. Materials employed

2. Throwing power and cathode efficiency

3. Plating range

4. Bent cathode tests 39

VI. Results obtained

1 Research associate of the American Electroplaters' Society. During the past few years, this society, composed chiefly of foreman platers, has collected a research fund from its members and from firms engaged in electroplating. This fund is used to pay the salaries and traveling expenses of research associates engaged at the Bureau of Standards in investigations upon plating problems. This paper presents the results obtained in one of these researches, 
VII. Discussion of results

1. Temperature and current density

2. Composition of solutions

(a) Chromic acid

(b) Sulphate 46

(c) Soluble additions 46

(1) Sodium dichromate

(2) Boric acid.

(d) Trivalent chromium

(e) Iron

3. Composition and condition of base metal 48

4. Bent cathode tests. 48

VIII. Conclusions

\section{INTRODUCTION}

In recent years chromium plating has come into very extensive use, especially upon such articles as automobile and plumbing fixtures, where appearance and resistance to tarnish and abrasion are important. One of the greatest difficulties in chromium plating is the poor throwing power, which makes it hard to deposit chromium in the recesses of irregularly shaped articles. No marked improvements in throwing power have been brought about in recent years, and the present commercial success in chromium plating is due more to the ingenuity of the platers than to the use of any new principles'or discoveries.

The published researches on the behavior of the chromic acid baths now used for chromium plating show that there is little hope of making radical improvements in their throwing power. It was believed however that a systematic study of all the factors involved would probably permit the selection of conditions which would at least yield somewhat more uniform metal distribution than is commonly obtained. As will be shown, this prediction has been justified.

\section{HISTORICAL}

Although many papers have been published upon chromium plating, in some of which the throwing power is referred to or discussed, very few specific researches have been published on this subject. H. E. Haring and W. P. Barrows ${ }^{2}$ reported no actual measurements of throwing power, but from a consideration of the factors involved, they concluded that "it is doubtful whether the throwing power of the chromic acid plating bath can be decidedly improved by the necessarily limited changes which can be made in its composition." They then predicted that the most favorable conditions for good throwing power would be (1) a relatively low concentration of chromic acid; (2) relatively high temperature and current density; (3) deposition on a metal of high hydrogen overvoltage, such as copper; (4) closing the circuit by the introduction of the cathode; and (5) using a reverse current on iron or steel for a few minutes.

$R$. Schneidewind in a comprehensive summary of his own and other researches on chromium plating ${ }^{3}$ made little distinction between the throwing power and the bright plating range which, as will be explained, are closely related to each other, but by no means identical. 
Most of his qualitative conclusions regarding throwing power apparently referred more to the range of bright deposits than to the relative thicknesses of the deposits, which latter factor determines the throwing power as quantitatively defined. While it is possible to derive definite values of throwing power from Schneidewind's data on cathode efficiencies, no such quantitative conclusions were drawn by that author.

O. J. Sizelove ${ }^{4}$ employed cathodes bent at right angles to measure the relative throwing powers under different conditions. He found that a low sulphate content and a high current density are favorable for good throwing power.

W. L. Pinner and E. M. Baker ${ }^{5}$ also used bent cathodes to measure the throwing power and thus defined the optimum ratio of chromic acid to sulphate in the baths.

In addition to the above publications, many other papers include discussions of or qualitative references to the throwing power of chromic acid solutions, but so far as known, no quantitative values of the throwing power have been published.

\section{PRINCIPLES INVOLVED}

\section{THROWING POWER}

(a) DEFINITIONS

While it is readily possible to make qualitative observations upon throwing power by plating recessed articles, such as bent cathodes or other irregular shapes, it is not feasible to express such results upon a numerical basis that is suitable for quantitative comparisons. The definition of and method of measuring throwing power that will be used in this paper are those which were described in previous papers from this bureau. ${ }^{6}$ These principles may be summarized as follows:

Upon any irregularly shaped cathode there is a certain "primary current distribution," determined solely by the shapes and relative positions of the cathode, the anode, and the container. This current distribution is that which is produced when there is no cathode polarization, for example, when an alternating current of sufficiently high frequency is used. It is independent of the composition or properties of the plating solution. If a far part $F$ of a cathode is five times as far from the anode as a near part $N$ (and hence the resistance from the anode to $F$ is five times that to $N$ ) the primary current density on the far part will be only one-fifth that on the near part. If this primary current distribution prevails, and if the efficiency of deposition is the same at the two current densities, the "metal distribution" on these two points will also be $5: 1$, and the metal coating will be five times as thick on the near as on the far part.

- If, however, by some property of the solution or of the plating process the metal ratio is made $4: 1$ instead of $5: 1$, the article is more uniformly plated, and there is a positive "throwing power." This is defined as the improvement, in per cent, of the metal distribution ratio above the primary current ratio. If the metal distribution ratio

4 Monthly Rev. Am. Electroplaters' Soc., 16, April, 1929.

5 Trans. Am. Electrochem. Soc., 55, preprint; 1929.

6 H. E. Haring and W. Blum, Current Distribution and Throwing Power in Electrodeposition, Trans. Am. Electrochem. Soc., 44, p. 313; 1923. H. E. Haring, Throwing Power, Cathode Potentials and Efficiencies in Nickel Deposition, Trans. Am. Electrochem. Soc., 46, p. 107; 1924, 
is $4: 1$ and the primary ratio is $5: 1$, the throwing power is $\frac{5-4}{5}=\frac{1}{5}=$ +20 per cent. If in another case the metal ratio is $6: 1$ instead of $5: 1$, the metal is less uniformly distributed than corresponds to the shape and position of the article. The throwing power is then negative, and is equal to $\frac{5-6}{5}=-\frac{1}{5}=-20$ per cent. As will be shown, the throwing power in the present chromic acid baths is invariably negative, and the best that can be hoped is to make it less negative. Thus a throwing power of -25 per cent is better than one of -100 per cent, even though both are negative, and poor compared with the throwing power in nickel and copper deposition.

In order to measure the throwing power, all that is necessary is a rectangular box in which a perforated anode and two plane cathodes (connected together) are placed at definite distances, so that they completely fill the cross section of the solution. Of these plates $N$ represents a near point on the cathode and $F$ a far point. By weighing these cathodes before and after plating the weights of deposits on the two are determined. From these weights and the relative distances from the anode the throwing power is easily calculated.

Thus, if the plates are, respectively, 5 and $10 \mathrm{~cm}$ (2 and 4 inches) from the anode, the primary ratio is $2: 1$. If then the metal deposit on the near plate weighs $0.637 \mathrm{~g}$ and on the far plate $0.232 \mathrm{~g}$, the metal ratio is $\frac{0.637}{0.232}=2.74$. The throwing power is therefore.

$$
\frac{2-2.74}{2.0}=-\frac{0.74}{2}=-0.37=-37 \text { per cent }
$$

The numerical values obtained for throwing power depend upon the size and shape of the throwing-power box and the primary ratio employed. While the data obtained in a given apparatus are comparable with each other, they are not directly comparable with those obtained in a different apparatus. For uniformity it is suggested that the box (or rather the solution) have a cross section of 5 by 5 $\mathrm{cm}$ ( 2 by 2 inches) and a distance between cathodes of $15 \mathrm{~cm}$ (6 inches $)^{7}$ For most plating solutions a primary ratio of $5: 1$ is satisfactory, but for chromium plating a ratio of $2: 1$ is preferable because satisfactory deposits can seldom be obtained with a current ratio as great as $5: 1$. All published results for throwing power should include a statement of the primary ratio.

\section{(b) FACTORS INVOLVED}

It has been shown by Haring and Blum ${ }^{8}$ that the throwing power depends only upon three factors, viz, (1) cathode polarization, (2) conductivity, and (3) cathode efficiency. Their effects may be summarized as follows, with special reference to chromium plating.

(1) Cathode polarization.-When any metal is deposited upon a cathode, the concentration of metal in the adjacent solution (the cathode film) decreases, and hence a higher potential is required to cause metal deposition than from the original concentration. This increase in potential is called the cathode polarization. In general,

\footnotetext{
${ }_{7}$ Such an apparatus, which is useful also for measuring polarization and conductivity is now available from the State Manufacturing Co., of Chicago, Ill.

8 See footnote 6, p. 29.
} 
it increases as the current density is increased. Typical cathode and anode polarization curves for chromium deposition are shown in Figure 1, reprinted from Bureau of Standards Technologic Paper No. 346.

As shown in Figure 2 (from B. S. Tech. Paper No. 346) the total voltage drop between the anode and cathode in any electrolysis is the sum of (1) the decomposition potential; (2) the IR drop, which is the product of the current $I$ and resistance $R$; (3) the wnode polarization; and (4) the cathode polarization. For simplicity we may consider that in a given operation (1) and (3) are constant. Then the rest of the voltage is equal to the $I R$ drop plus the cathode polarization. The total voltage between the anode and the near and far parts of the cathode, respectively, is the same if the anode and

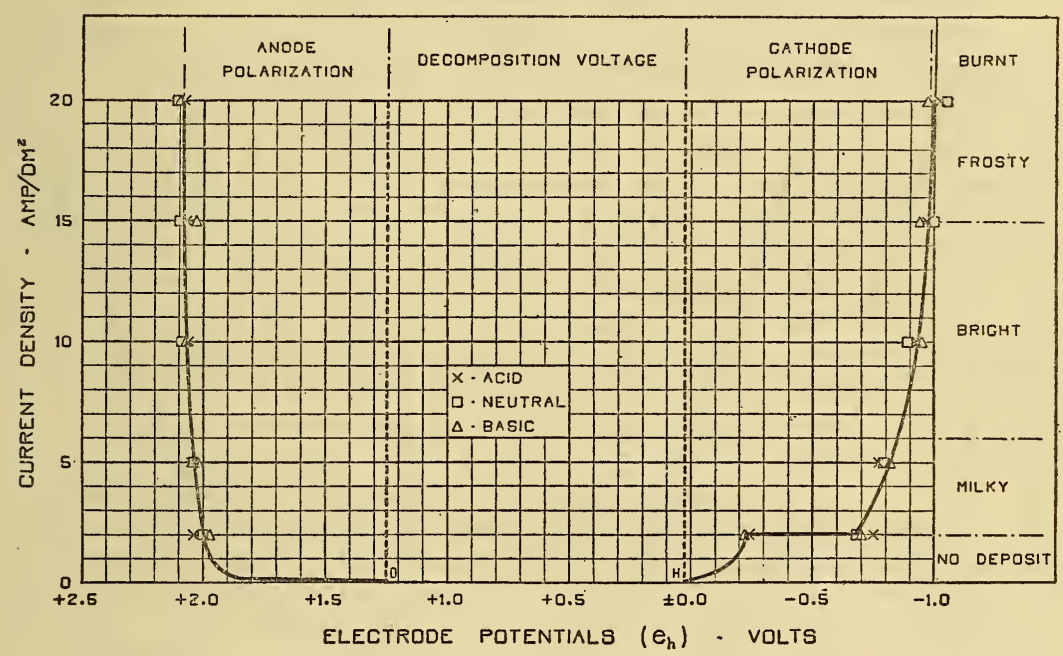

FIgURE 1.-Electrode potentials in chromium deposition

$\mathrm{CrO}_{3}-250 \mathrm{~g} / \mathrm{L} ; \mathrm{SO}_{4}-0.25 \mathrm{~g} / \mathrm{L} ; 45^{\circ} \mathrm{C}$.; lead anode; steel cathode.

cathode are good conductors. Any increase in cathode polarization due to the higher current density on the near point will necessarily result in a lower $I R$ drop to that point. As for a given solution, the resistance to the near point is fixed, the current $I$ and, hence, the current density on the near point must decrease and become more nearly equal to that on the far point. This tendency to equalize the current densities causes an increase in throwing power: In general, the throwing power is better when the cathode polarization increases greatly with an increase in current density.

Actually in chromium plating as shown in Figure 1, the cathode polarization increases very slightly with the current density within the range of bright deposits. Hence, there can be no appreciable positive throwing power in chromic acid solutions.

(2) Conductivity. - The conductivity (or resistivity) of the solution determines the $I R$ drop through a certain path with a given current. By increasing the conductivity the value of $I R$ is decreased. This increases the relative effect of any change in cathode polarization upon the throwing power. If, however, as in chromium plating, the

$84789^{\circ}-29-3$ 
change in cathode polarization is small, the effect of an improvement in conductivity is also negligible. Any effect of conductivity is rendered still less significant by the fact that high current densities are used in chromium plating and, hence, the $I R$ drop is high even when $R$ is low. The conductivity of the chromic acid solution, therefore, has no appreciable effect on the throwing power.

(3) Cathode efficiency.-If the cathode efficiency increases as the current density is increased, this tends to make the metal coating relatively thicker at the near point, where the current density is high, than corresponds to the actual or "secondary" current distribution. This represents a decrease in throwing power, which

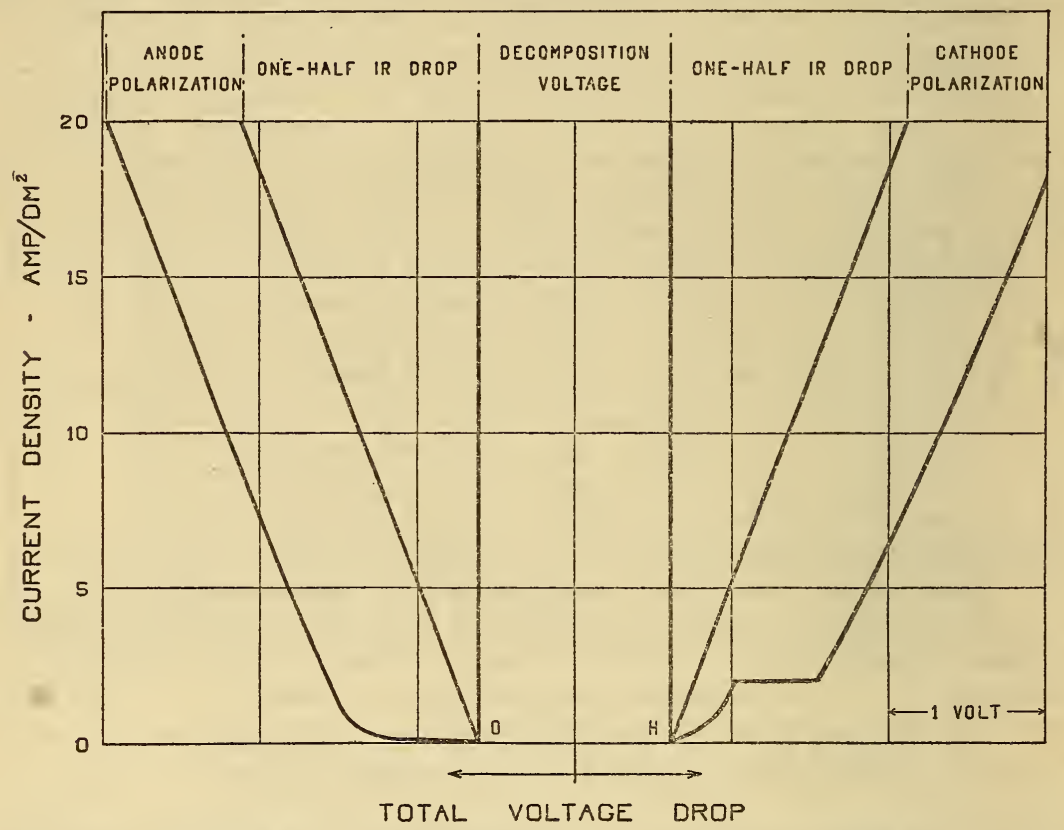

FIgURe 2.-Total voltage used in chromium deposition $\mathrm{CrO}_{3}-250 \mathrm{~g} / \mathrm{L} ; \mathrm{SO}_{4}-0.25 \mathrm{~g} / \mathrm{L} ; 45^{\circ} \mathrm{C}$; lead anode; steel cathode; $10 \mathrm{~cm}$ apart.

then may become negative. Suppose that, as a result of cathode polarization, the current densities on the near and far plates are in the ratio of $1.8: 1$ when the primary ratio is $2: 1$. This corresponds to a throwing power of +10 per cent if the cathode efficiencies are equal at the two current densities. But if, as is probable in chromium plating, the cathode efficiency is 15 per cent on the near plate and 10 per cent on the far plate, the actual weights (or thicknesses) of the metal on the two plates are in the ratio of

$$
\frac{1.8}{1.0} \times \frac{15}{10}=\frac{2.7}{1.0}=2.7: 1
$$

and the throwing power is

$$
\frac{2-2.7}{2.0}=-0.35=-35 \text { per cent }
$$


A negative throwing power is possible only if the cathode efficiency increases with the current density. This condition exists whenever, as in nickel and chromium deposition, it is easier to discharge hydrogen than metal. At some low current density only hydrogen will be liberated, but as the current density increases to a certain value, metal starts to deposit. Further increases in current density improve the cathode efficiency. This condition is the principal cause of the poor throwing power in chromium plating. Hence, the only hope of improving the throwing power is to employ those conditions under which the current efficiency is most nearly uniform for the maximum and minimum current densities. This investigation has resolved itself largely into a study of cathode efficiencies in chromium deposition.

\section{PLATING RANGE}

In all plating processes the crystal structure and luster of the deposits are affected by the conditions of deposition, such as temperature and current density. Chromium is not unusual except in so far as (a) the conditions for producing bright deposits are more restricted than with most other metals, and $(b)$ as the hardness and difficulty of polishing chromium make it more important to produce bright deposits initially. In consequence, the conditions employed for chromium plating, at least for ornamental purposes, are fixed almost entirely by the "plating range" of bright deposits, and throwing power as above defined is generally a secondary factor. The chief concern usually is to produce a bright chromium coating: over the entire surface to be plated, regardless of the relative thickness in the depressions. To a large degree this course is warranted when the coatings are primarily for appearance.

The range of temperature and current density within which bright deposits are obtainable can be determined experimentally for any solution, and plotted as shown in Figure 3 (from B. S. Tech. Paper No. 346). Such curves are, however, only approximate because it is hard to decide at the border lines just which deposits are bright, milky, frosty, or burnt.

\section{COVERING POWER}

The ability to completely cover a cathode, which may be referred to as the "covering power," is closely related to the throwing power as above defined, but is not so readily defined quantitatively. Strictly speaking, the covering power relates to the process or extent of covering the cathode, while the throwing power (as here defined) is an expression of the relative thicknesses of the deposits on two parts of the cathode after they are covered. As will be shown by the tests with bent cathodes, the covering power is practically parallel to the throwing power. The data for the latter are, however, more useful for quantitative comparisons.

\section{METHODS OF REGULATING THE PRIMARY CURRENT DISTRIBUTION}

Research and experience have shown that, for a given solution and temperature, bright chromium deposits can be produced only between certain current densities, and that, in general, the covering power and throwing power are poor. It is obvious that if a cathode is of such 
a shape, or can be so placed in the bath, that the current density is uniform over the entire surface, the difficulties of plating range, covering power, and throwing power will entirely disappear. Such a state exists only under ideal conditions which can seldom be obtained or maintained. It is possible, however, by proper ingenuity to obtain more nearly uniform current densities than exist under usual conditions, and thus largely overcome the above difficulties. It is rarèly possible to plate completely with bright chromium any object on which the maximum current density is more than five times the minimum. For general work it is desirable to reduce this ratio to

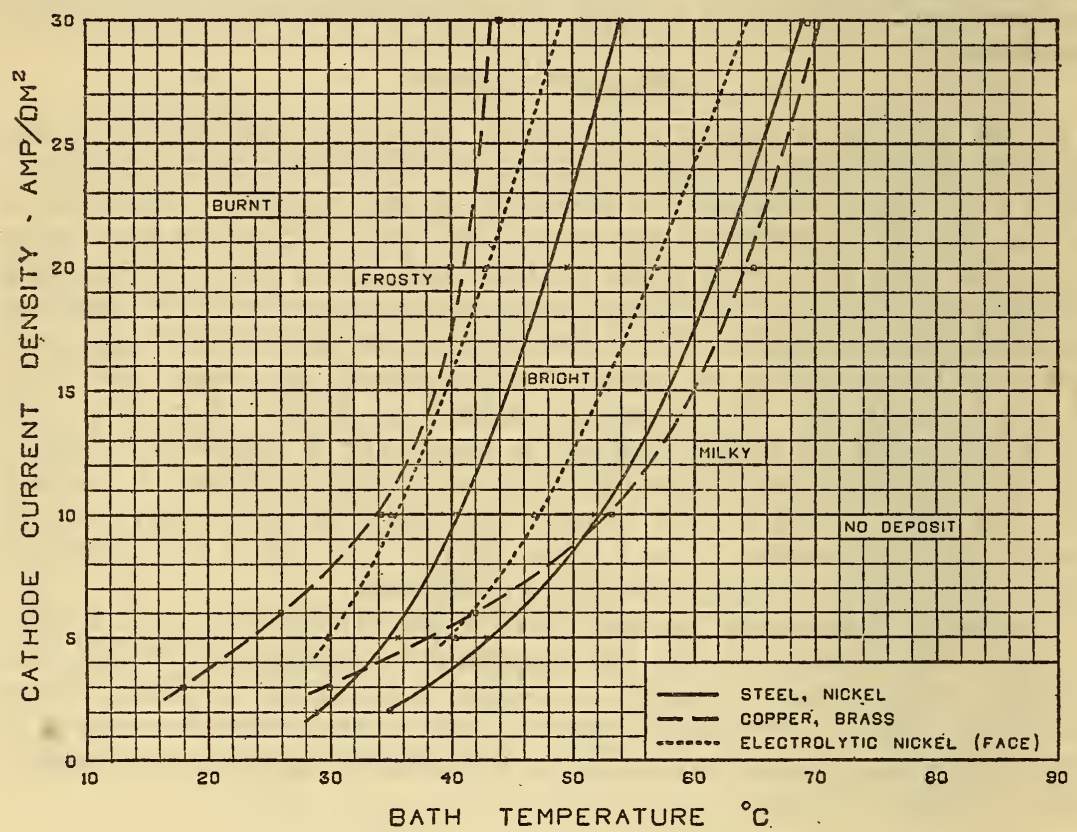

FIGURE 3.-Plating range on different metals

$\mathrm{CrO}_{3}-250 \mathrm{~g} / \mathrm{L} ; \mathrm{SO}_{4}-0.25 \mathrm{~g} / \mathrm{L}$.

not more than 3 to 1 . This can be accomplished (or approached) by four methods, all of which have long been used for other kinds of plating. They are especially useful for chromium plating. .

\section{USE OF CONCENTRIC OR PARALLEL ANODES AND CATHODES}

When the cathodes are plane surfaces, the current density can be made almost exactly uniform by having parallel anodes, which, as well as the cathodes, completely fill the cross section of the solution. Cylindrical tubes can be plated uniformly by having anode rods inside them or cylindrical anodes surrounding them. The same principle is involved in the use of inside anodes of any kind, such as those used in plating parabolic lamp reflectors. Experience has shown that for such purposes exact parallelism is not necessary and may be undesirable. This is because of secondary effects due to unequal heating or circulation and to the passage of excess currents 
to points and edges. In general, all such arrangements must be based on trial. They are not practicable when the articles are of very irregular shapes.

\section{INCREASING THE DISTANCE BETWEEN THE ANODES AND CATHODES}

When an article of irregular shape is relatively close to the anode, the near points receive much higher current densities than the far points in the depressions. By simply moving the articles farther from the anode the current densities are made more uniform. Suppose, for example, that a cup-shaped piece has a depth of $10 \mathrm{~cm}$ (4 inches) and is hung so that the edge is only $2.5 \mathrm{~cm}$ ( 1 inch) from the anode; then the current density on the edge will be at least five times as great as in the bottom. Actually the ratio will be much larger, owing to the tendency of projecting points or edges to receive an excessive current through the surrounding solution, and for the depression to be shielded so as to get comparatively few current lines. By moving the cathode so that the edge is $10 \mathrm{~cm}$ (4 inches) from the anode, the current density there will be only about twice that in the recess. By moving it still farther away the ratio will become still more nearly unity.

The practical objection to this procedure is that by increasing the average distance between the anodes and cathodes, the voltage necessary for securing a given current density must also be increased. This is especially objectionable if the available potential is not more than 6 volts. In that case the distance must be fixed by the maximum voltage. Actually in chromium plating this objection is not so serious as in other plating because (see fig. 2) the IR drop, the only factor affected by the distance, represents only a small part of the total voltage. Under most conditions an increase in average distance from 10 to $20 \mathrm{~cm}$ (4 to 8 inches) involves not more than 20 per cent increase in voltage; for example, an increase from 5 to 6 volts. This method of securing uniform current densities is especially adapted for plating small parts, as then even when the tank is "full" the anode area is usually larger than the cathode area, which relation reduces the necessary voltage (and is otherwise desirable). Practically, average distances of 20 to $30 \mathrm{~cm}$ ( 8 to 12 inches) are found advantageous.

\section{USE OF ADJACENT CONDUCTORS}

It has long been the practice of electroplaters, especially when producing thick metal deposits as in electroforming, to attach metal wires or rods to the cathodes, near those parts which otherwise tend to receive excessive current densities and "burnt" deposits. The wire serves to attract part of the current and, in the language of the oldtime platers, acts as a "thief." This principle has been very successfully applied in chromium plating, especially of small parts having sharp projections on which a "burnt" deposit is likely to form. When these articles are hung on metal racks in such a way that the exposed points are adjacent to a metal rod which forms part of the rack, or to other parts of the cathodes, the current density is made more uniform on the articles, and complete plating can be accomplished without burning on the projections. In some cases a wire cage or basket is attached so as to surround the projecting points. 


\section{USE OF NONMETALLIC SHIELDS}

Another way to prevent the current density from being excessive on the projecting portions of the cathode is to shield them by strips of insulating material such as glass, bakelite, or hard rubber. This method is the least convenient and is used only in extreme cases. One difficulty is that of obtaining insulating materials that are not attacked by the warm, strong chromic acid baths. When, as is now a frequent practice, wire-glass linings are used in the plating tanks, the hanging of articles so that projecting parts are near the side of the tank results in a shielding of this type.

\section{METHODS OF STUDY}

\section{MATERIALS EMPLOYED}

The chromic acid used in these tests was a high-grade commercial product furnished for electroplating. Analyses of this material showed that it contained 99.5 per cent $\mathrm{CrO}_{3}, 0.2$ per cent $\mathrm{Cr}_{2} \mathrm{O}_{3}$, 0.08 per cent $\mathrm{SO}_{4}$, and 0.20 per cent insoluble matter. As sulphate and trivalent chromium were present in much smaller concentrations than those to be added to most of the baths, no attempt was made to purify this chromic acid.

"Chemically pure" sulphuric acid was used to furnish the desired sulphate content, except in those few solutions in which other sulphates are designated. The latter were added in the form of analyzed stock solutions of "reagent chemicals," as was also the sodium dichromate used in a few baths.

Stock solutions of chromic acid with a high content of trivalent chromium, subsequently determined by analysis, were prepared by (a) electrolyzing chromic acid with platinum electrodes, and (b) dissolving in chromic acid dry chromium hydroxide, that contained a small amount of sulphate, which was determined and allowed for in the solutions prepared from this material. The results were identical with solutions of the same concentrations prepared by these two methods.

All chromium plating solutions were analyzed by the methods described in Bureau of Standards Technologic Paper No. 346. The compositions of the principal solutions used in this study are shown in Table 1. 


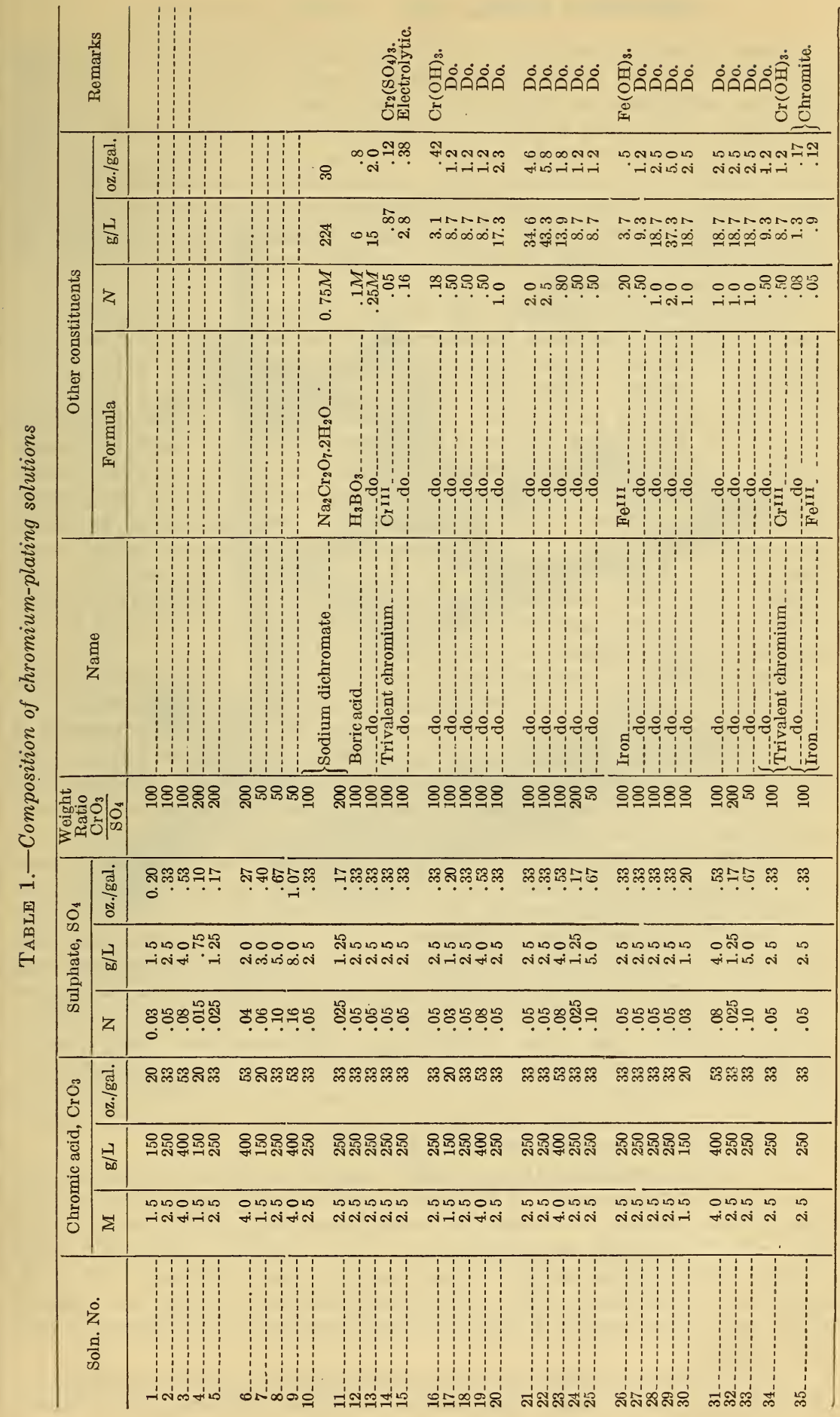




\section{THROWING POWER AND CATHODE EFFICIENCY}

It was found impracticable to use the regular hard-rubber throwing power box, as the rubber was slowly attacked by the chromic acid, with the simultaneous reduction of the latter to trivalent chromium. Attempts to have an accurately dimensioned glass box made in one piece have not thus far succeeded. A box made of plate glass with joints sealed with a mixture of powdered silica and sodium silicate, baked at $150^{\circ} \mathrm{C}$. $\left(300^{\circ} \mathrm{F}\right.$.) was unsatisfactory, as the cement was slowly attacked by the solutions. Joints made similarly with a mixture of sodium silicate (grade $\mathrm{S}$ ) and silica-gel lasted somewhat longer, but were not permanent.

The box finally adopted (fig. 4) for this purpose consisted of a heavy steel box, screwed together so as to be water-tight without cement. This box was lined with plate-glass strips, with edges accurately ground. The glass box was not absolutely water-tight, but tests showed that there was no significant electrical leakage through the joints. A platinum-gauze anode and two sheet cathodes, usually of steel, were held in place at the top by a bakelite frame, and at the bottom by strips of thin glass (not shown in the figure) that covered the bottom of the box. The cross section of the solution was 5 by $5 \mathrm{~cm}$ ( 2 by 2 inches) and the two cathodes were, respectively, 5 and $10 \mathrm{~cm}$ ( 2 and 4 inches) from the anode. The primary ratio was therefore $2: 1$. This ratio was adopted in order to cover a wider range of plating conditions than will yield bright deposits with a greater ratio, such as 5 to 1 .

The box was set in a water thermostat. The temperature of the latter was controlled so as to maintain the desired temperature in the cell, which as the result of the passage of current was usually a few degrees higher than that of the surrounding water bath. The solution in the box was maintained at the designated temperatures to $\pm 1^{\circ} \mathrm{C}$. Unless otherwise stated the time of deposition in each experiment was 30 minutes.

In order to determine in the same experiment the throwing power and the cathode efficiencies on the two plates, it was necessary to measure the currents passing to the two cathodes. In the initial experiments this was done by means of two copper coulometers, each connected in sories with a cathode. An adjustable resistance was also in one circuit in order to maintain the two cathodes at the same potential with respect to the anode. This arrangement yielded reliable results, but was cumbersome and required very careful adjustment. The results showed that the secondary current ratio was almost exactly $2: 1$, and never less than $1.9: 1$. This shows that there was no appreciable difference between the polarizations at the current densities used on the two cathodes.

In the later experiments precision ammeters were substituted for the copper coulometers. The currents were sufficiently constant to permit the number of coulombs to be measured within about 2 per cent, which precision was adequate, as the cathode efficiencies were seldom reproducible within 5 per cent of their values. Thus in duplicate experiments the cathode efficiencies on the two plates might be in one case 10.3 and 17.6 per cent, and in another 9.9 and 18.2 per cent.

As the current distribution was practically $2: 1$, the measurements of throwing power really represented cathode efficiency determina- 


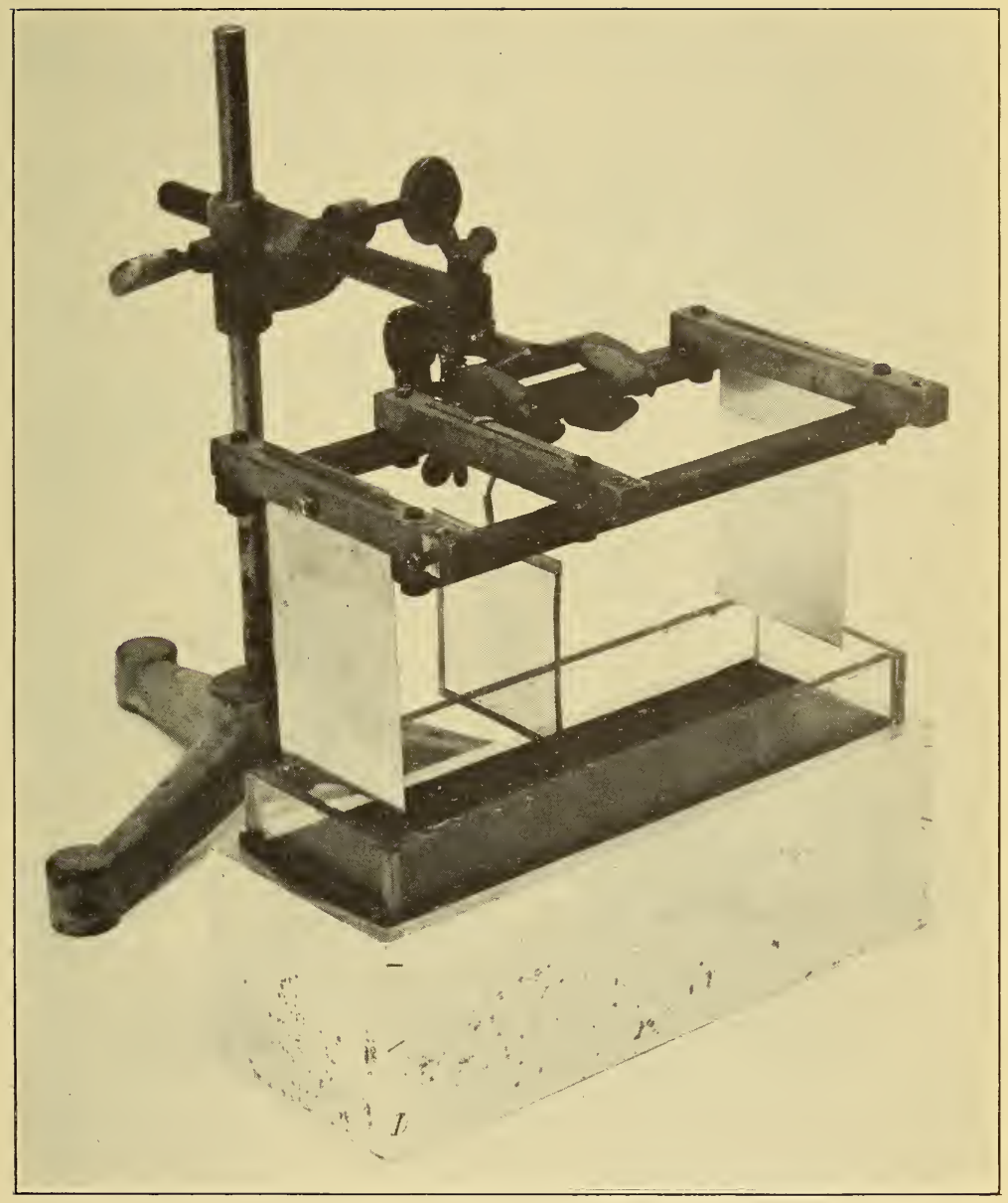

FIgURe 4.-Throwing power box

A steel box lined with glass. Platinum gauze anode and steel cathodes 


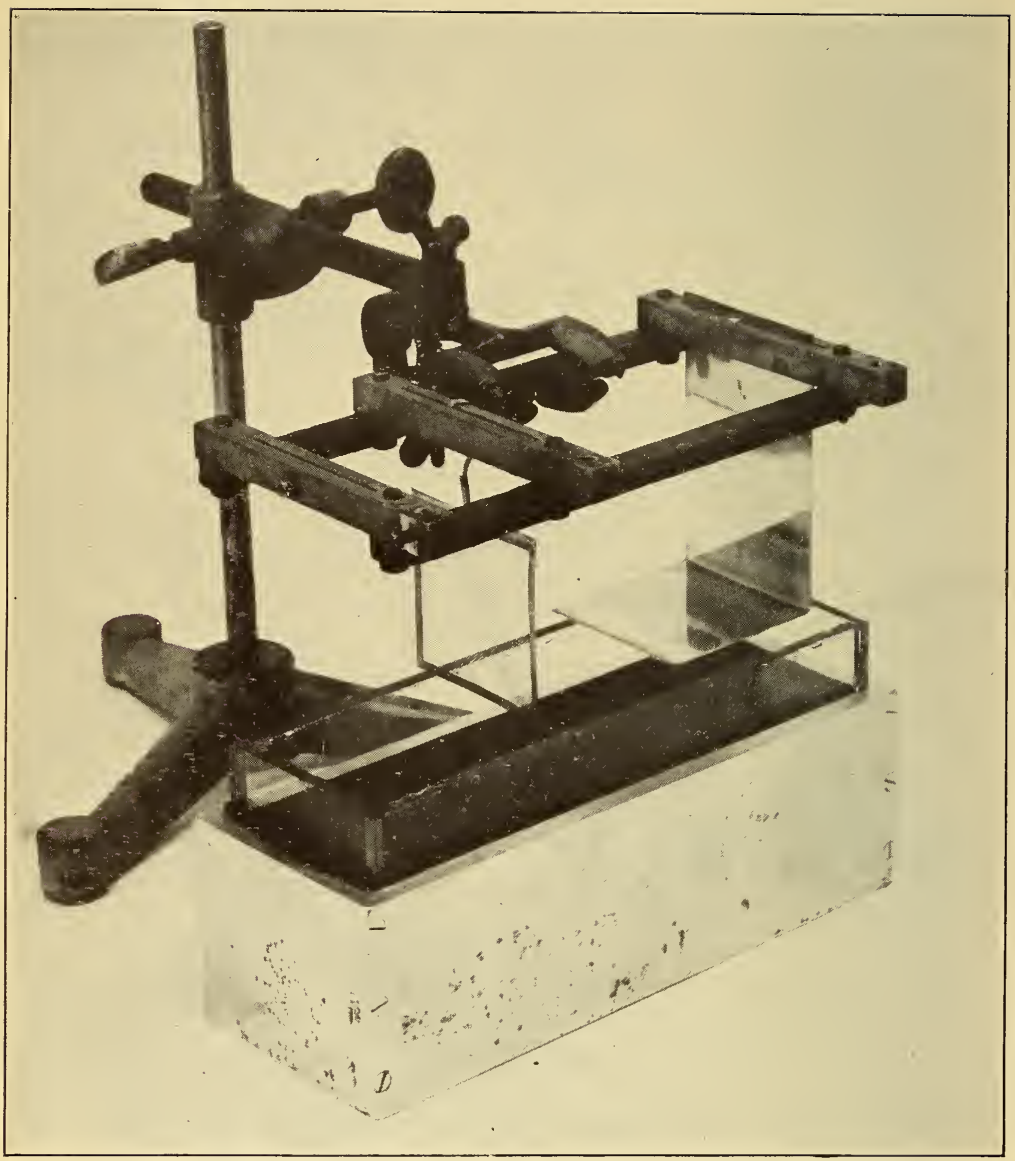

FIGURE 5.-Arrangement for bent cathode test

Platinum gauze anode and copper cathode. 
tions, which might have been made in other apparatus than the throwing-power box, which, for this purpose, was simply a means of obtaining definite and uniform current densities on plane parallel plates of known dimensions. The results in the box were, however, more significant than if, as is all to common practice, the cathodes were suspended in jars of larger cross section, in which case the current densities would not have been so nearly uniform over the cathodes, and the recorded cathode efficiencies would have been simply averages for the existing current densities.

\section{PLATING RANGE}

All deposits produced in the throwing-power experiments were classified (by two observers) as milky (M), bright (Br), frosty (F), and burnt $(\mathrm{Bu})$. As there are no sharp lines between these groups, the designations were necessarily approximate. Additional experiments were made near the dividing lines, in order to fix the latter as definitely as possible. One reason that the data of this study may not agree exactly with those of other observers, is that in our experiments the current densities were more uniform than in most of the other recorded measurements. Another reason is that these deposits were made upon steel, on which the plating range is narrower than on copper or brass.

\section{BENT CATHODE TESTS}

In order to determine whether the results for throwing power represent, or are at least parallel to, those that would be obtained in actual plating, experiments were made with bent cathodes, such as have been used by Sizelove and by Pinner and Baker. In this investigation the test was made somewhat more quantitative and more closely related to the throwing power by the following modifications.

As shown in Figure 5, the cathode, usually of polished copper, was $5 \mathrm{~cm}$ (2 inches) wide, and was bent at a sharp right angle, so that the horizontal portion, and also the vertical portion that was immersed in the solution, were each 5 by $5 \mathrm{~cm}$ ( 2 by 2 inches). The cathode was placed at one end of the throwing-power box with the horizontal portion resting on the bottom; and a plane anode, which may be of sheet lead (though the platinum gauze was used in most of our tests) was placed at a distance of $10 \mathrm{~cm}$ ( 4 inches) from the vertical portion of the cathode. The minimum distances from the anode to the horizontal and vertical parts of the cathode were therefore 5 and $10 \mathrm{~cm}$ ( 2 and 4 inches), respectively. Hence, this ratio was 2 to 1 , just as in the throwing-power experiments. Actually the current densities were not uniform on the two parts of the cathode, but decreased as the angle was approached. The extent to which the cathode was covered defined the covering power, which, as will be seen, was practically parallel to the throwing power as previously measured. Preliminary tests showed that the area covered did not change noticeably after plating for five minutes. This period was, therefore, employed in the experiments.

\section{RESULTS OBTAINED}

In the following tables the data have been assembled in such a way as to emphasize the effects of each variable. Even then it is necessary to refer to different tables to bring out the full comparisons, 
as it would involve too much repetition to include all comparable data in each table. The experiment numbers refer to the order in which they were conducted, and are included simply for reference. The solution numbers refer to Table 1, which contains details regarding composition and preparation.

The average current density is the arithmetical mean of the current densities on the near and far plates. As previously noted, the observed current densities were always in the ratio of 2 to 1 , within a few per cent. The actual current density on the near plate was, therefore,

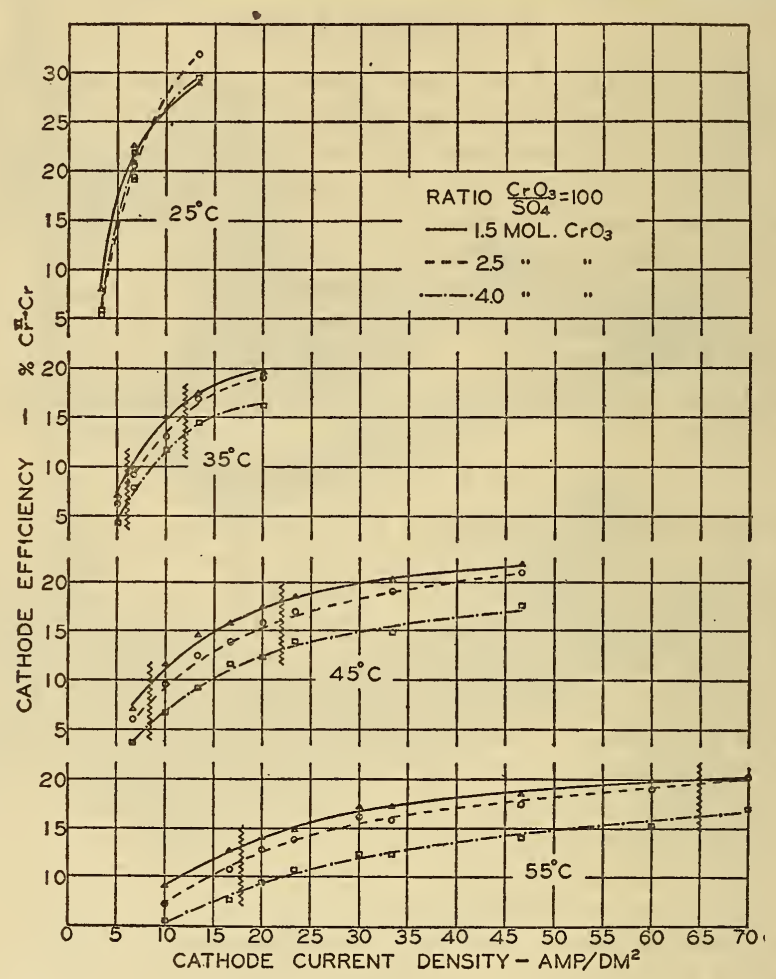

FIGURE 6.-Effect of temperature and chromic acid concentration on cathode efficiency

Bright deposits obtained between wavy lines.

practically 1.33 times the average and on the far plate 0.67 times the average.

The voltage represents the total drop between the anode and cathode. The numerical values of voltage apply only to the arrangement and dimensions of this box, but they indicate qualitatively the relative voltages that would be required for any given arrangement in commercial baths.

The cathode efficiencies have been computed from the readings of current and time and the weights of deposit. They are all based on hexavalent chromium. Tests showed that with polished cathodes they were reproducible to within about 5 per cent of their values. As the cathode efficiencies represent the most important factor in chromium plating, they have been plotted in Figures 6 to 9 . 


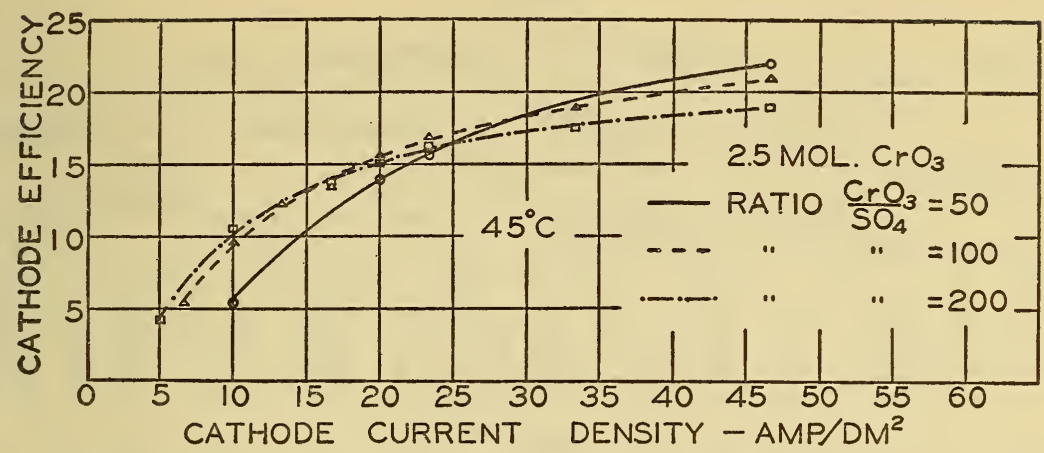

FIgURe 7.-Effect of sulphate ratio on cathode efficiency

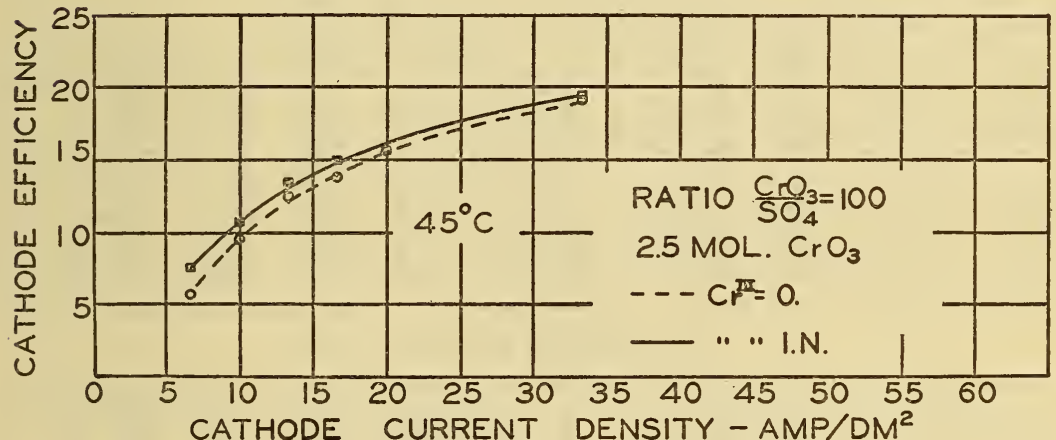

FIGURE 8.-Effect of trivalent chromium on cathode efficiency

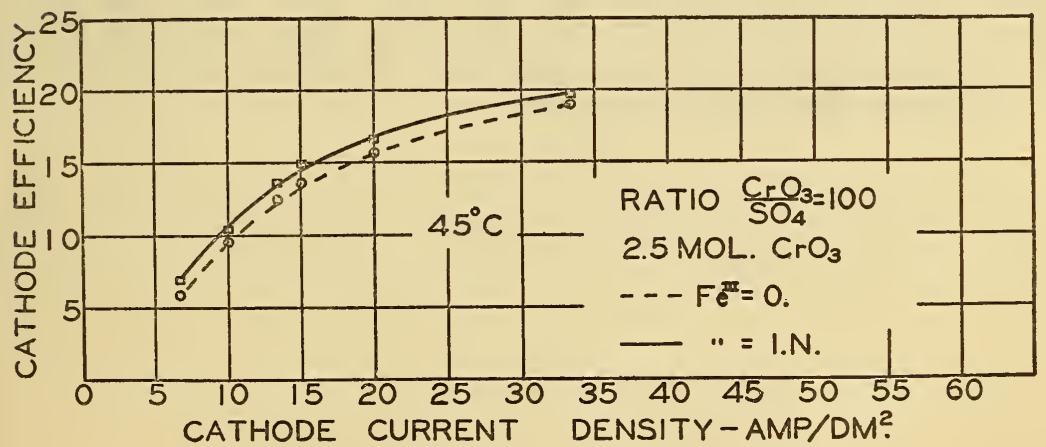

FIGURE 9.-Effect of iron on cathode efficiency 
TABLE 2.-Effect of temperature and current density on throwing power

$\mathrm{CrO}_{3} / \mathrm{SO}_{4}=100$

(A) SOLUTION No. $1,150 \mathrm{~g} / \mathrm{L} \mathrm{CrO}_{3}$

\begin{tabular}{|c|c|c|c|c|c|c|c|c|c|c|c|}
\hline \multirow{2}{*}{ Experiment No. } & \multicolumn{2}{|c|}{ Temperature } & \multicolumn{2}{|c|}{$\begin{array}{l}\text { Average cur- } \\
\text { rent density }\end{array}$} & \multirow{2}{*}{ Volts } & \multicolumn{3}{|c|}{ Cathode efficiency } & \multirow{2}{*}{$\begin{array}{l}\text { Throw- } \\
\text { ing } \\
\text { power }\end{array}$} & \multicolumn{2}{|c|}{ Appearance 1} \\
\hline & ${ }^{\circ} \mathrm{C}$. & ${ }^{\circ} \mathrm{F}$. & Amp./ & Amp./ & & Near & Far & A verage & & Near & Far \\
\hline $\begin{array}{l}1 .- \\
7 \\
10 \\
13 \\
16 .\end{array}$ & $\begin{array}{l}25 \\
35 \\
35 \\
35 \\
45\end{array}$ & $\begin{array}{r}77 \\
95 \\
95 \\
95 \\
113\end{array}$ & $\begin{array}{l}5 \\
7.5 \\
10 \\
15 \\
15\end{array}$ & $\begin{array}{r}47 \\
70 \\
93 \\
140 \\
140\end{array}$ & $\begin{array}{l}3.9 \\
4.1 \\
4.6 \\
5.4 \\
5.2\end{array}$ & $\begin{array}{c}\text { Per cent } \\
22.6 \\
16.3 \\
17.4 \\
19.6 \\
17.7\end{array}$ & $\begin{array}{c}\text { Per cent } \\
8.0 \\
6.9 \\
9.5 \\
13.8 \\
11.7\end{array}$ & $\begin{array}{r}\text { Per cent } \\
15.3 \\
11.6 \\
13.5 \\
16.7 \\
14.7\end{array}$ & $\begin{array}{c}\text { Per cent } \\
-204 \\
-127 \\
-84 \\
-43 \\
-50\end{array}$ & $\begin{array}{l}\mathrm{Bu} \\
\mathrm{Br} \\
\mathrm{F} \\
\mathrm{F} \\
\mathrm{Br}\end{array}$ & $\begin{array}{l}\mathrm{M} \\
\mathrm{Br} \\
\mathrm{Br} \\
\mathrm{Br} \\
\mathrm{Br}\end{array}$ \\
\hline $\begin{array}{l}19 \\
22 \\
25 \\
28 \\
31\end{array}$ & $\begin{array}{l}45 \\
45 \\
55 \\
55 \\
55\end{array}$ & $\begin{array}{l}113 \\
113 \\
131 \\
131 \\
131\end{array}$ & $\begin{array}{l}25 \\
35 \\
25 \\
35 \\
45\end{array}$ & $\begin{array}{l}230 \\
325 \\
230 \\
325 \\
420\end{array}$ & $\begin{array}{l}6.7 \\
7.8 \\
6.2 \\
7.6 \\
8.9\end{array}$ & $\begin{array}{l}20.2 \\
21.7 \\
16.9 \\
18.5 \\
19.6\end{array}$ & $\begin{array}{l}15.7 \\
18.2 \\
12.7 \\
14.7 \\
17.2\end{array}$ & $\begin{array}{l}17.9 \\
19.9 \\
14.8 \\
16.6 \\
18.4\end{array}$ & $\begin{array}{l}-26 \\
-19 \\
-33 \\
-23 \\
-13\end{array}$ & $\begin{array}{l}\mathrm{F} \\
\mathrm{F} \\
\mathrm{Br} \\
\mathrm{Br} \\
\mathrm{Br}\end{array}$ & $\begin{array}{l}\mathrm{Br} \\
\mathrm{F} \\
\mathrm{M} \\
\mathrm{Br} \\
\mathrm{Br}\end{array}$ \\
\hline
\end{tabular}

(B) SOLUTION No. 2, $250 \mathrm{~g} / \mathrm{L} \mathrm{CrO}_{3}$

\begin{tabular}{|c|c|c|c|c|c|c|c|c|c|c|c|}
\hline $\begin{array}{ll}2 \\
8 \\
11 \\
14\end{array}$ & $\begin{array}{l}25 \\
35 \\
35 \\
35 \\
45\end{array}$ & $\begin{array}{r}77 \\
95 \\
95 \\
95 \\
113\end{array}$ & $\begin{array}{r}5 \\
7.5 \\
10 \\
15 \\
15\end{array}$ & $\begin{array}{r}47 \\
70 \\
93 \\
140 \\
140\end{array}$ & $\begin{array}{l}3.9 \\
3.9 \\
4.3 \\
4.8 \\
4.6\end{array}$ & $\begin{array}{l}19.2 \\
14.3 \\
17.2 \\
19.3 \\
15.9\end{array}$ & $\begin{array}{r}5.4 \\
6.5 \\
9.3 \\
12.0 \\
9.9\end{array}$ & $\begin{array}{l}12.3 \\
10.4 \\
13.2 \\
15.6 \\
12.9\end{array}$ & $\begin{array}{l}-295 \\
-108 \\
-87 \\
-58 \\
-65\end{array}$ & $\begin{array}{l}\mathrm{Bu} \\
\mathrm{F} \\
\mathrm{F} \\
\mathrm{F} \\
\mathrm{Br}\end{array}$ & $\begin{array}{l}\mathrm{M} \\
\mathrm{M} \\
\mathrm{Br} \\
\mathrm{Br} \\
\mathrm{Br}\end{array}$ \\
\hline $\begin{array}{l}20 \ldots \\
23 \\
26 \\
29 \\
32\end{array}$ & $\begin{array}{l}45 \\
45 \\
55 \\
55 \\
55\end{array}$ & $\begin{array}{l}113 \\
113 \\
131 \\
131 \\
131\end{array}$ & $\begin{array}{l}25 \\
35 \\
25 \\
35 \\
45\end{array}$ & $\begin{array}{l}230 \\
325 \\
230 \\
325 \\
420\end{array}$ & $\begin{array}{l}5.8 \\
6.8 \\
5.5 \\
6.4 \\
7.5\end{array}$ & $\begin{array}{l}19.0 \\
21.0 \\
15.7 \\
17.9 \\
19.5\end{array}$ & $\begin{array}{l}13.6 \\
17.0 \\
10.8 \\
13.8 \\
16.7\end{array}$ & $\begin{array}{l}16.3 \\
19.0 \\
13.3 \\
15.8 \\
18.1\end{array}$ & $\begin{array}{l}-27 \\
-23 \\
-46 \\
-28 \\
-14\end{array}$ & $\begin{array}{l}\mathrm{F} \\
\mathrm{F} \\
\mathrm{Br} \\
\mathrm{Br} \\
\mathrm{Br}\end{array}$ & $\begin{array}{l}\mathrm{Br} \\
\mathrm{F} \\
\mathrm{M} \\
\mathrm{Br} \\
\mathrm{Br}\end{array}$ \\
\hline
\end{tabular}

(C) SOLUTION No. 3, $400 \mathrm{~g} / \mathrm{L} \mathrm{CrO}_{3}$

\begin{tabular}{|c|c|c|c|c|c|c|c|c|c|c|c|}
\hline $\begin{array}{l}3 \\
12 \\
18 \\
18\end{array}$ & $\begin{array}{l}25 \\
35 \\
35 \\
35 \\
45\end{array}$ & $\begin{array}{r}77 \\
95 \\
95 \\
95 \\
113\end{array}$ & $\begin{array}{l}5 \\
7.5 \\
10 \\
15 \\
15\end{array}$ & $\begin{array}{r}47 \\
70 \\
93 \\
140 \\
140\end{array}$ & $\begin{array}{l}3.9 \\
3.8 \\
4.1 \\
4.7 \\
4.5\end{array}$ & $\begin{array}{l}21.8 \\
12.2 \\
19.5 \\
15.9 \\
12.2\end{array}$ & $\begin{array}{r}5.9 \\
4.1 \\
7.7 \\
11.3 \\
6.7\end{array}$ & $\begin{array}{r}13.8 \\
8.1 \\
11.1 \\
13.6 \\
9.5\end{array}$ & $\begin{array}{l}-312 \\
-177 \\
-87 \\
-59 \\
-85\end{array}$ & $\begin{array}{l}\mathrm{Bu} \\
\mathrm{Br} \\
\mathrm{F} \\
\mathrm{F} \\
\mathrm{Br}\end{array}$ & $\begin{array}{l}\mathrm{M} \\
\mathrm{M} \\
\mathrm{Br} \\
\mathrm{Br} \\
\mathrm{Br}\end{array}$ \\
\hline $\begin{array}{l}21 \\
24 \\
27 \\
30\end{array}$ & $\begin{array}{l}45 \\
45 \\
55 \\
55 \\
55\end{array}$ & $\begin{array}{l}113 \\
113 \\
131 \\
131 \\
131\end{array}$ & $\begin{array}{l}25 \\
35 \\
25 \\
35 \\
45\end{array}$ & $\begin{array}{l}230 \\
325 \\
230 \\
325 \\
420\end{array}$ & $\begin{array}{l}5.4 \\
6.2 \\
5.1 \\
6.0 \\
6.8\end{array}$ & $\begin{array}{l}14.4 \\
17.9 \\
11.6 \\
14.1 \\
15.2\end{array}$ & $\begin{array}{r}12.0 \\
14.2 \\
7.7 \\
10.8 \\
12.6\end{array}$ & $\begin{array}{r}13.2 \\
16.0 \\
9.6 \\
12.5 \\
13.9\end{array}$ & $\begin{array}{l}-28 \\
-25 \\
-52 \\
-29 \\
-18\end{array}$ & $\begin{array}{l}\mathrm{F} \\
\mathrm{F} \\
\mathrm{Br} \\
\mathrm{Br} \\
\mathrm{Br}\end{array}$ & $\begin{array}{l}\mathrm{Br} \\
\mathrm{F} \\
\mathrm{M} \\
\mathrm{Br} \\
\mathrm{Br}\end{array}$ \\
\hline
\end{tabular}

$1 \mathrm{M}=$ milky; $\mathrm{Br}=$ bright, $\mathrm{F}=$ frosty; $\mathrm{Bu}=$ burnt. 


\section{TABLE 3:-Effect of sulphate ratio on throwing power}

(A) $\mathrm{CrO}_{3} / \mathrm{SO}_{4}=50$

\begin{tabular}{|c|c|c|c|c|c|c|c|c|c|c|c|c|}
\hline \multirow{2}{*}{$\begin{array}{c}\text { Experi- } \\
\text { ment No. }\end{array}$} & \multirow{2}{*}{$\begin{array}{l}\text { Solu- } \\
\text { tion } \\
\text { No. }\end{array}$} & \multicolumn{2}{|c|}{ Temperature } & \multicolumn{2}{|c|}{$\begin{array}{l}\text { Average cur- } \\
\text { rent density }\end{array}$} & \multirow{2}{*}{ Volts } & \multicolumn{3}{|c|}{ Cathode efficiency } & \multirow{2}{*}{$\begin{array}{c}\text { Throw- } \\
\text { ing } \\
\text { power }\end{array}$} & \multicolumn{2}{|c|}{ Appearance } \\
\hline & & ${ }^{\circ} \mathrm{C}$ & ${ }^{\circ} \mathrm{F}$. & $\begin{array}{l}\text { Amp./ } \\
\text { dm. }\end{array}$ & $\mathrm{Amp}_{\mathrm{ft} .}{ }^{2} /$ & & Near & Far & A verage & & Near & Far \\
\hline $\begin{array}{l}48-- \\
43-- \\
37-- \\
35-- \\
40--- \\
46-- \\
50--\end{array}$ & $\begin{array}{l}7 \\
8 \\
8 \\
8 \\
8 \\
8 \\
9\end{array}$ & $\begin{array}{l}45 \\
35 \\
45 \\
45 \\
45 \\
55 \\
45\end{array}$ & $\begin{array}{r}113 \\
95 \\
113 \\
113 \\
113 \\
131 \\
113\end{array}$ & $\begin{array}{l}15 \\
15 \\
7.5 \\
15 \\
35 \\
15 \\
15\end{array}$ & $\begin{array}{r}140 \\
140 \\
70 \\
140 \\
325 \\
140 \\
140\end{array}$ & $\begin{array}{l}5.0 \\
4.8 \\
3.3 \\
4.7 \\
6.7 \\
4.4 \\
4.4\end{array}$ & $\begin{array}{c}\text { Per cent } \\
16.5 \\
\text { \}ourren } \\
13.9 \\
21.7 \\
\text { Curren } \\
11.8\end{array}$ & \begin{tabular}{|}
$\left|\begin{array}{r}\text { Per cent } \\
9.5\end{array}\right|$ \\
t variabl \\
$\left|\begin{array}{r}5.4 \\
15.9 \\
\mid t \\
\text { variabl } \\
6.0\end{array}\right|$
\end{tabular} & 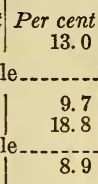 & $\left\{\begin{array}{c}P e r \text { cent } \\
-61 \\
-117 \\
-154 \\
-34 \\
-350 \\
-113\end{array} \mid\right.$ & $\begin{array}{l}\mathrm{Br} \\
\mathrm{F} \\
\mathrm{M} \\
\mathrm{Br} \\
\mathrm{F} \\
\mathrm{Br} \\
\mathrm{Br}\end{array}$ & $\begin{array}{c}\mathrm{Br} \\
\mathrm{Br} \\
\text { No dep. } \\
\mathrm{M} \\
\mathrm{Br} \\
\mathrm{M} \\
\mathrm{M}\end{array}$ \\
\hline
\end{tabular}

(B) $\mathrm{CrO}_{5} / \mathrm{SO}_{4}=200$

\begin{tabular}{|c|c|c|c|c|c|c|c|c|c|c|c|c|}
\hline $\begin{array}{l}47- \\
54- \\
41- \\
42-\end{array}$ & $\begin{array}{l}4 \\
5 \\
5 \\
5\end{array}$ & $\begin{array}{l}45 \\
35 \\
35 \\
35\end{array}$ & $\begin{array}{r}113 \\
95 \\
95 \\
95\end{array}$ & $\begin{array}{l}15 \\
7.5 \\
10 \\
15\end{array}$ & $\begin{array}{r}140 \\
70 \\
93 \\
140\end{array}$ & $\begin{array}{l}5.0 \\
\text { 3. } \\
4.1 \\
4.8\end{array}$ & $\begin{array}{l}17.3 \\
14.5 \\
16.4 \\
18.6\end{array}$ & $\begin{array}{r}12.4 \\
9.0 \\
12.1 \\
13.3\end{array}$ & $\begin{array}{l}14.8 \\
11.7 \\
14.2 \\
15.9\end{array}$ & $\begin{array}{l}-38 \\
-62 \\
-37 \\
-37\end{array}$ & $\begin{array}{l}\mathrm{Br} \\
\mathrm{Br} \\
\mathrm{F} \\
\mathrm{F}\end{array}$ & $\begin{array}{l}\mathrm{Br} \\
\mathrm{Br} \\
\mathrm{Br} \\
\mathrm{Br}\end{array}$ \\
\hline $\begin{array}{l}36 .- \\
34- \\
38 \\
39\end{array}$ & $\begin{array}{l}5 \\
5 \\
5 \\
5\end{array}$ & $\begin{array}{l}45 \\
45 \\
45 \\
45\end{array}$ & $\begin{array}{l}113 \\
113 \\
113 \\
113\end{array}$ & $\begin{array}{c}7.5 \\
15 \\
25 \\
35\end{array}$ & $\begin{array}{r}70 \\
140 \\
230 \\
325\end{array}$ & $\begin{array}{l}3.8 \\
4.7 \\
5.7 \\
6.8\end{array}$ & $\begin{array}{l}10.7 \\
15.2 \\
17.3 \\
18.9\end{array}$ & $\begin{array}{r}4.2 \\
10.4 \\
13.7 \\
16.4\end{array}$ & $\begin{array}{r}7.5 \\
12.8 \\
15.5 \\
17.7\end{array}$ & $\begin{array}{l}-143 \\
-52 \\
-27 \\
-15\end{array}$ & $\begin{array}{l}\mathrm{Br} \\
\mathrm{Br} \\
\mathrm{F} \\
\mathrm{F}\end{array}$ & $\begin{array}{l}\mathrm{M} \\
\mathrm{Br} \\
\mathrm{Br} \\
\mathrm{F}\end{array}$ \\
\hline $\begin{array}{l}45- \\
44- \\
53- \\
49-\end{array}$ & $\begin{array}{l}5 \\
5 \\
6 \\
6\end{array}$ & $\begin{array}{l}55 \\
55 \\
35 \\
45\end{array}$ & $\begin{array}{r}131 \\
131 \\
95 \\
113\end{array}$ & $\begin{array}{c}15 \\
35 \\
7.5 \\
15\end{array}$ & $\begin{array}{r}140 \\
325 \\
70 \\
140\end{array}$ & $\begin{array}{l}4.4 \\
6.4 \\
3.9 \\
4.4\end{array}$ & $\begin{array}{l}11.3 \\
15.0 \\
14.5 \\
12.2\end{array}$ & $\begin{array}{r}5.4 \\
13.4 \\
9.0 \\
7.3\end{array}$ & $\begin{array}{r}8.4 \\
14.2 \\
11.7 \\
9.8\end{array}$ & $\begin{array}{l}-102 \\
-13 \\
-62 \\
-62\end{array}$ & $\begin{array}{l}\mathrm{M} \\
\mathrm{Br} \\
\mathrm{Br} \\
\mathrm{Br}\end{array}$ & $\begin{array}{l}\mathrm{M} \\
\mathrm{Br} \\
\mathrm{Br} \\
\mathrm{M}\end{array}$ \\
\hline
\end{tabular}

TABLE 4.-Effects of soluble additions on throwing power $250 \mathrm{~g} / \mathrm{L} \mathrm{CrO} 3$

(A) $\mathrm{Na}_{2} \mathrm{Cr}_{2} \mathrm{O}_{7}$

\begin{tabular}{|c|c|c|c|c|c|c|c|c|c|c|c|c|}
\hline \multirow{2}{*}{$\begin{array}{c}\text { Experi- } \\
\text { ment No. }\end{array}$} & \multirow{2}{*}{$\begin{array}{l}\text { Solu- } \\
\text { tion } \\
\text { No. }\end{array}$} & \multicolumn{2}{|c|}{ Temperature } & \multicolumn{2}{|c|}{$\begin{array}{l}\text { Average cur- } \\
\text { rent density }\end{array}$} & \multirow{2}{*}{ Volts } & \multicolumn{3}{|c|}{ Cathode efficiency } & \multirow{2}{*}{$\begin{array}{l}\text { Throw- } \\
\text { ing } \\
\text { power }\end{array}$} & \multicolumn{2}{|c|}{ Appearance } \\
\hline & & ${ }^{\circ} \mathrm{C}$. & ${ }^{\circ} \mathrm{F}$. & Amp./ & Amp./I & & Near & Far & A verage & & Near & Far \\
\hline $\begin{array}{l}56-- \\
55-- \\
57=-\end{array}$ & $\begin{array}{l}10 \\
10 \\
11\end{array}$ & $\begin{array}{l}35 \\
45 \\
45\end{array}$ & $\begin{array}{r}95 \\
113 \\
113\end{array}$ & $\begin{array}{l}7.5 \\
15 \\
15\end{array}$ & $\begin{array}{r}70 \\
140 \\
140\end{array}$ & $\begin{array}{l}4.0 \\
4.9 \\
4.8\end{array}$ & \begin{tabular}{|c} 
Per cent \\
12.6 \\
11.8 \\
6.2
\end{tabular} & \begin{tabular}{|c} 
Per cent \\
6.0 \\
7.7 \\
3.1
\end{tabular} & $\begin{array}{r}\text { Per cent } \\
9.3 \\
9.7 \\
4.6\end{array}$ & \begin{tabular}{|c} 
Per cent \\
-103 \\
-50 \\
-100
\end{tabular} & $\begin{array}{l}\mathrm{F} \\
\mathrm{Br} \\
\mathrm{Br}\end{array}$ & $\begin{array}{l}\mathrm{M} \\
\mathrm{Br} \\
\mathrm{Br}\end{array}$ \\
\hline
\end{tabular}

(B) $\mathrm{H}_{3} \mathrm{BO}_{3}$

\begin{tabular}{l|l|l|l|l|l|l|l|l|l|l|l|l}
\hline 58 & 12 & 45 & 113 & 15 & 140 & 4.4 & 15.8 & 9.4 & 12.6 & -64 & $\mathrm{Br}$ & $\mathrm{Br}$ \\
$59 .---.--$ & 13 & 45 & 113 & 15 & 140 & 4.5 & 15.6 & 9.2 & 12.4 & -67 & $\mathrm{Br}$ & $\mathrm{Br}$ \\
\hline
\end{tabular}


TABLE 5.-Effect of trivalent chromium

\begin{tabular}{|c|c|c|c|c|c|c|c|c|c|c|c|c|c|}
\hline \multirow{2}{*}{$\begin{array}{l}\text { Ex- } \\
\text { peri- } \\
\text { ment } \\
\text { No. }\end{array}$} & \multirow{2}{*}{$\mid \begin{array}{c}\text { Solu- } \\
\text { tion } \\
\text { No. }\end{array}$} & \multirow{2}{*}{$\stackrel{\mathrm{Cr}_{N}^{\mathrm{III}}}{N}$} & \multicolumn{2}{|c|}{ Temperature } & \multicolumn{2}{|c|}{$\begin{array}{l}\text { A verage cur- } \\
\text { rent density }\end{array}$} & \multirow{2}{*}{ Volts } & \multicolumn{3}{|c|}{ Cathode efficiency } & \multirow{2}{*}{$\begin{array}{c}\text { Throw- } \\
\text { ing } \\
\text { power }\end{array}$} & \multicolumn{2}{|c|}{ Appearance } \\
\hline & & & ${ }^{\circ} \mathrm{C}$ & ${ }^{\circ} \mathrm{F}$. & $\underset{\mathrm{dm} .2}{\mathrm{Amp}} / /$ & Amp./ & & Near & Far & Average & & Near & Far \\
\hline 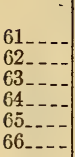 & $\begin{array}{l}14 \\
15 \\
15 \\
16 \\
16 \\
18\end{array}$ & $\begin{array}{l}0.05 \\
.16 \\
.16 \\
.18 \\
.18 \\
.50\end{array}$ & $\begin{array}{l}45 \\
45 \\
55 \\
45 \\
55 \\
45\end{array}$ & $\begin{array}{l}113 \\
113 \\
131 \\
113 \\
131 \\
113\end{array}$ & $\begin{array}{l}15 \\
15 \\
35 \\
15 \\
35 \\
15\end{array}$ & $\begin{array}{l}140 \\
140 \\
325 \\
140 \\
325 \\
140\end{array}$ & $\begin{array}{l}4.5 \\
4.6 \\
6.7 \\
4.6 \\
7.3 \\
4.8\end{array}$ & $\begin{array}{c}\text { Per cent } \\
15.6 \\
16.4 \\
18.6 \\
16.4 \\
18.8 \\
16.3\end{array}$ & \begin{tabular}{|r|} 
Per cent \\
9.1 \\
9.8 \\
14.2 \\
9.8 \\
14.2 \\
10.5
\end{tabular} & \begin{tabular}{|r|} 
Per cent \\
12.4 \\
13.1 \\
16.4 \\
13.1 \\
16.5 \\
13.4
\end{tabular} & $\begin{array}{r}\text { Per cent } \\
-70 \\
-64 \\
-30 \\
-64 \\
-27 \\
-57\end{array}$ & $\begin{array}{l}\mathrm{Br} \\
\mathrm{Br} \\
\mathrm{Br} \\
\mathrm{Br} \\
\mathrm{Br} \\
\mathrm{Br}\end{array}$ & $\begin{array}{l}\mathrm{Br} \\
\mathrm{Br} \\
\mathrm{Br} \\
\mathrm{Br} \\
\mathrm{Br} \\
\mathrm{Br}\end{array}$ \\
\hline $\begin{array}{l}67 . \\
80 . \\
68 . \\
81 . \\
69 .\end{array}$ & $\begin{array}{l}18 \\
20 \\
20 \\
20 \\
20\end{array}$ & $\begin{array}{r}.50 \\
1.00 \\
1.00 \\
1.00 \\
1.00\end{array}$ & $\begin{array}{l}55 \\
45 \\
45 \\
45 \\
55\end{array}$ & $\begin{array}{l}131 \\
113 \\
113 \\
113 \\
131\end{array}$ & $\begin{array}{l}35 \\
10 \\
15 \\
25 \\
35\end{array}$ & $\begin{array}{r}325 \\
93 \\
140 \\
230 \\
325\end{array}$ & $\begin{array}{l}7.3 \\
4.6 \\
5.5 \\
7.1 \\
8.8\end{array}$ & $\begin{array}{l}18.1 \\
13.6 \\
15.6 \\
19.2 \\
17.0\end{array}$ & $\begin{array}{r}14.0 \\
7.9 \\
10.7 \\
15.1 \\
14.0\end{array}$ & $\begin{array}{l}16.0 \\
10.8 \\
13.1 \\
17.1 \\
15.5\end{array}$ & $\begin{array}{l}-27 \\
-71 \\
-43 \\
-26 \\
-22\end{array}$ & $\begin{array}{l}\mathrm{Br} \\
\mathrm{Br} \\
\mathrm{Br} \\
\mathrm{F} \\
\mathrm{Br}\end{array}$ & $\begin{array}{l}\mathrm{Br} \\
\mathrm{M} \\
\mathrm{Br} \\
\mathrm{Br} \\
\mathrm{Br}\end{array}$ \\
\hline $\begin{array}{l}74 . \\
75- \\
76- \\
77-\end{array}$ & $\begin{array}{l}21 \\
21 \\
22 \\
22 \\
17\end{array}$ & $\begin{array}{l}2.0 \\
2.0 \\
2.5 \\
2.5 \\
.50\end{array}$ & $\begin{array}{l}45 \\
55 \\
45 \\
55 \\
45\end{array}$ & $\begin{array}{l}113 \\
131 \\
113 \\
131 \\
113\end{array}$ & $\begin{array}{l}15 \\
35 \\
15 \\
35 \\
15\end{array}$ & $\begin{array}{l}140 \\
325 \\
140 \\
325 \\
140\end{array}$ & $\begin{array}{c}7.0 \\
12+ \\
10 \\
12+ \\
6.0\end{array}$ & $\begin{array}{c}15.1 \\
\text { Insuffic } \\
\text { Deposi } \\
\text { Insuffic } \\
17.7\end{array}$ & $\begin{array}{l}11.6 \\
\text { cient volt } \\
\text { ts rough } \\
\text { cient volt } \\
12.3\end{array}$ & $\begin{array}{l}13.4 \\
\text { tage. } \\
\text { and disco } \\
\text { tage. }\end{array}$ & -29 & $\mathrm{Br}$ & $\mathrm{Br}$ \\
\hline $\begin{array}{l}71 \\
72 . \\
73- \\
78 . \\
79 .\end{array}$ & $\begin{array}{l}19 \\
24 \\
25 \\
23 \\
23\end{array}$ & $\begin{array}{l}.50 \\
.50 \\
.50 \\
.80 \\
.80\end{array}$ & $\begin{array}{l}45 \\
45 \\
45 \\
45 \\
55\end{array}$ & $\begin{array}{l}113 \\
113 \\
113 \\
113 \\
131\end{array}$ & $\begin{array}{l}15 \\
15 \\
15 \\
15 \\
35\end{array}$ & $\begin{array}{l}140 \\
140 \\
140 \\
140 \\
325\end{array}$ & $\begin{array}{l}4.5 \\
4.9 \\
4.9 \\
4.7 \\
6.8\end{array}$ & $\begin{array}{l}\text { 12. } 2 \\
14.9 \\
15.1 \\
13.2 \\
14.3\end{array}$ & $\begin{array}{r}7.4 \\
10.1 \\
8.0 \\
8.1 \\
11.3\end{array}$ & $\begin{array}{r}9.8 \\
12.5 \\
11.6 \\
10.7 \\
12.8\end{array}$ & $\begin{array}{l}-64 \\
-46 \\
-86 \\
-61 \\
-24\end{array}$ & $\begin{array}{l}\mathrm{Br} \\
\mathrm{Br} \\
\mathrm{Br} \\
\mathrm{Br} \\
\mathrm{Br}\end{array}$ & $\begin{array}{l}\mathrm{Br} \\
\mathrm{Br} \\
\mathrm{Br} \\
\mathrm{Br} \\
\mathrm{Br}\end{array}$ \\
\hline
\end{tabular}

TABLE 6.-Effect of iron

\begin{tabular}{|c|c|c|c|c|c|c|c|c|c|c|c|c|c|}
\hline \multirow{2}{*}{$\begin{array}{l}\text { Ex- } \\
\text { peri- } \\
\text { ment } \\
\text { No. }\end{array}$} & \multirow{2}{*}{$\begin{array}{l}\text { Soiu- } \\
\text { tion } \\
\text { No. }\end{array}$} & \multirow{2}{*}{$\begin{array}{c}\mathrm{Fe}_{N} \mathrm{III} \\
\mathrm{N}\end{array}$} & \multicolumn{2}{|c|}{ Temperature } & \multicolumn{2}{|c|}{$\begin{array}{l}\text { Average cur- } \\
\text { rent density }\end{array}$} & \multirow{2}{*}{ Volts } & \multicolumn{3}{|c|}{ Cathode efficiency } & \multirow{2}{*}{$\begin{array}{c}\text { Throw- } \\
\text { ing } \\
\text { power }\end{array}$} & \multicolumn{2}{|c|}{ Appearance } \\
\hline & & & ${ }^{\circ} \mathrm{C}$. & ${ }^{\circ} \mathrm{F}$. & Amp./ & Amp./ & & Near & Far & A verage & & Near & Far \\
\hline $\begin{array}{l}83-- \\
84-- \\
85- \\
86- \\
89 .-\end{array}$ & $\begin{array}{l}26 \\
26 \\
27 \\
27 \\
28\end{array}$ & $\begin{array}{r}0.20 \\
.20 \\
.50 \\
.50 \\
1.0\end{array}$ & $\begin{array}{l}45 \\
55 \\
45 \\
55 \\
45\end{array}$ & $\begin{array}{l}113 \\
131 \\
113 \\
131 \\
113\end{array}$ & $\begin{array}{l}15 \\
35 \\
15 \\
35 \\
10\end{array}$ & $\begin{array}{r}140 \\
325 \\
140 \\
325 \\
93\end{array}$ & $\begin{array}{l}4.6 \\
6.9 \\
4.7 \\
7.2 \\
4.4\end{array}$ & $\begin{array}{c}\text { Per cent } \\
15.9 \\
17.7 \\
16.0 \\
17.8 \\
13.7\end{array}$ & $\begin{array}{c}\text { Per cent } \\
9.2 \\
13.8 \\
10.2 \\
13.8 \\
6.9\end{array}$ & $\begin{array}{r}\text { Per cent } \\
12.6 \\
15.7 \\
13.1 \\
15.8 \\
10.3\end{array}$ & $\begin{array}{r}\text { Per cent } \\
-71 \\
-27 \\
-56 \\
-27 \\
-105\end{array}$ & $\begin{array}{l}\mathrm{Br} \\
\mathrm{Br} \\
\mathrm{Br} \\
\mathrm{F} \\
\mathrm{Br}\end{array}$ & $\begin{array}{l}\mathrm{Br} \\
\mathrm{Br} \\
\mathrm{Br} \\
\mathrm{Br} \\
\mathrm{M}\end{array}$ \\
\hline $\begin{array}{l}87 . \\
90 . \\
88- \\
96 . \\
97 .\end{array}$ & $\begin{array}{l}28 \\
28 \\
28 \\
29 \\
29\end{array}$ & $\begin{array}{l}1.0 \\
1.0 \\
1.0 \\
2.0 \\
2.0\end{array}$ & $\begin{array}{l}45 \\
45 \\
55 \\
45 \\
55\end{array}$ & $\begin{array}{l}113 \\
113 \\
131 \\
113 \\
113\end{array}$ & $\begin{array}{l}15 \\
25 \\
35 \\
15 \\
35\end{array}$ & $\begin{array}{l}140 \\
230 \\
325 \\
140 \\
325\end{array}$ & $\begin{array}{r}5.1 \\
6.8 \\
8.3 \\
7.8 \\
12+\end{array}$ & $\begin{array}{r}16.3 \\
19.7 \\
18.2 \\
16.7 \\
\text { Insuffic }\end{array}$ & $\begin{array}{r}10.4 \\
15.0 \\
14.5 \\
12.0 \\
\text { ent volt }\end{array}$ & $\begin{array}{r}13.4 \\
17.3 \\
16.3 \\
14.4 \\
\text { tage. }\end{array}$ & $\begin{array}{l}-55 \\
-29 \\
-25 \\
-37\end{array}$ & $\begin{array}{l}\mathrm{Br} \\
\mathrm{F} \\
\mathrm{F} \\
\mathrm{F}\end{array}$ & $\begin{array}{l}\mathrm{Br} \\
\mathrm{Br} \\
\mathrm{Br} \\
\mathrm{Br}\end{array}$ \\
\hline $\begin{array}{l}92 . \\
93 . \\
94- \\
95\end{array}$ & $\begin{array}{l}30 \\
31 \\
32 \\
33\end{array}$ & $\begin{array}{l}1.0 \\
1.0 \\
1.0 \\
1.0\end{array}$ & $\begin{array}{l}45 \\
45 \\
45 \\
45\end{array}$ & $\begin{array}{l}113 \\
113 \\
113 \\
113\end{array}$ & $\begin{array}{l}15 \\
15 \\
15 \\
15\end{array}$ & $\begin{array}{l}140 \\
140 \\
140 \\
140\end{array}$ & $\begin{array}{l}7.5 \\
4.6 \\
5.3 \\
5.3\end{array}$ & $\begin{array}{l}17.6 \\
13.8 \\
15.5 \\
15.5\end{array}$ & $\begin{array}{r}12.5 \\
8.8 \\
11.5 \\
7.0\end{array}$ & $\begin{array}{l}15.0 \\
11.3 \\
13.5 \\
11.3\end{array}$ & $\begin{array}{r}-41 \\
-56 \\
-47 \\
-119\end{array}$ & $\begin{array}{l}\mathrm{Br} \\
\mathrm{F} \\
\mathrm{F} \\
\mathrm{Br}\end{array}$ & $\begin{array}{l}\mathrm{Br} \\
\mathrm{Br} \\
\mathrm{M} \\
\mathrm{Br}\end{array}$ \\
\hline
\end{tabular}

$\mathrm{Fe}+\mathrm{III}+\mathrm{CrII}^{\mathrm{III}}$

\begin{tabular}{r|r|r|r|r|r|r|r|r|r|r|r|r|r}
\hline $91 \ldots-$ & 34 & 0.5 & 45 & 113 & 15 & 140 & 5.5 & 16.4 & 10.6 & 13.5 & -58 & $\mathrm{Br}$ & $\mathrm{Br}$ \\
$100 \ldots$ & 35 & .55 & 45 & 113 & 15 & 140 & 4.6 & 16.2 & 9.2 & 12.7 & -71 & $\mathrm{Br}$ & $\mathrm{Br}$ \\
\hline
\end{tabular}


TABLE 7.-Effect of composition of base metal on throwing power

$250 \mathrm{~g} / \mathrm{L} \mathrm{CrO}_{3} ; \mathrm{CrO}_{3} / \mathrm{SO}_{4}=100 ; 45^{\circ}$ C. $\left(113^{\circ} \mathrm{F}.\right) ; 15 \mathrm{amp} . / \mathrm{dm} .{ }^{2}$

\begin{tabular}{|c|c|c|c|c|c|c|c|c|}
\hline \multirow[b]{2}{*}{ Experiment No. } & \multirow[b]{2}{*}{ Base metal } & \multirow[b]{2}{*}{ Volts } & \multicolumn{3}{|c|}{ Cathode efficiency } & \multirow{2}{*}{$\begin{array}{c}\text { Throw- } \\
\text { ing } \\
\text { power }\end{array}$} & \multicolumn{2}{|c|}{ Appearance } \\
\hline & & & Near & Far & $\begin{array}{l}\text { A ver- } \\
\text { age }\end{array}$ & & Near & Far \\
\hline $\begin{array}{l}17 \\
101- \\
102 \\
103\end{array}$ & 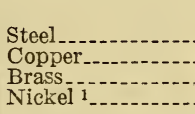 & $\begin{array}{l}4.6 \\
4.5 \\
4.5 \\
4.5\end{array}$ & \begin{tabular}{|c} 
Per cent \\
15.9 \\
16.0 \\
16.4 \\
16.3
\end{tabular} & $\begin{array}{r}\text { Per cent } \\
9.9 \\
8.2 \\
9.5 \\
8.5\end{array}$ & $\begin{array}{r}\text { Per cent } \\
12.9 \\
12.1 \\
12.9 \\
12.4\end{array}$ & $\mid \begin{array}{r}\text { Per cent } \\
-65 \\
-85 \\
-70 \\
-81\end{array}$ & $\begin{array}{l}\mathrm{Br} \\
\mathrm{Br} \\
\mathrm{Br} \\
\mathrm{Br}\end{array}$ & $\begin{array}{l}\mathrm{Br} \\
\mathrm{Br} \\
\mathrm{Br} \\
\mathrm{Br}\end{array}$ \\
\hline
\end{tabular}

1 Nickel-plated brass.

\section{DISCUSSION OF RESULTS}

As the throwing power may be affected by each of a number of variables, it is difficult, if not impossible, to select any one set of conditions as best. Instead, it will be most convenient to consider independently the effect of each variable. The actual choice of operating conditions will usually represent a compromise, owing to the limitations that may be imposed in a given plant by the character of work to be plated, the available voltage, and other factors.

\section{TEMPERATURE AND CURRENT DENSITY}

Table 2 shows clearly that raising the current density at a fixed temperature increases the throwing power; while an elevation in temperature at a fixed current density decreases the throwing power. The best throwing power in the range of bright deposits is obtained, however, at relatively high temperatures and current densities. The reason for this is evident from Figure 6 , in which it is shown that as the temperature is increased, the cathode efficiencies become more uniform within the range of bright deposits.

As the temperature of the bath is raised its conductivity is increased, and hence the voltage required to produce a given current density is decreased. But to produce bright deposits at the higher temperature the current density must be raised more than in proportion to the increase in conductivity. Consequently, a higher voltage is needed at a high temperature, such as $55^{\circ}$ C. $\left(131^{\circ} \mathrm{F}\right.$.), to produce bright deposits along with the superior throwing power than at some lower temperature.

Practically, it is advisable to employ as high a temperature and corresponding current density as other conditions permit. At room temperature, $25^{\circ} \mathrm{C}$. $\left(77^{\circ} \mathrm{F}\right.$.), it is possible to produce bright deposits upon copper or brass (but not on steel) when the current ratio is $2: 1$. Hence, if articles are satisfactorily plated at so low a temperature, they are probably of such a shape and in such a position in the bath that the current density is nearly uniform over each article. At temperatures up to $55^{\circ} \mathrm{C}$. ( $\left(131^{\circ} \mathrm{F}\right.$.) with appropriately high current densities, the throwing power approaches zero, which is the highest value that can be expected in view of the negligible effect of polarization. If, however, a 6-volt generator is used, a potential of not more than 5 volts is generally available between the electrodes. In that case a lower temperature, such as from $35^{\circ}$ to $45^{\circ} \mathrm{C}$. $\left(95^{\circ}\right.$ to $113^{\circ} \mathrm{F}$.) 
and as high current densities as will produce bright deposits, should be used. The actual temperature selected must be maintained within about $\pm 2^{\circ} \mathrm{C}$. $\left( \pm 4^{\circ} \mathrm{F}\right.$.) to obtain uniform results.

\section{COMPOSITION OF SOLUTIONS}

(a) CHROMIC ACID

Table 2 shows that as the concentration of chromic acid is raised while the ratio of chromic acid to sulphate is kept constant, the throwing power for given conditions decreases. This is because in every case, as shown in Figure 6, the cathode efficiencies are higher and more uniform in the more dilute solutions. When the maximum throwing power for a given current density is desired, a relatively dilute solution is advantageous. As, however, the less concentrated solution has a lower conductivity, a higher voltage is needed to produce a given current density. Thus in the box, at $45^{\circ} \mathrm{C}$. and 15 amp. $/ \mathrm{dm}^{2}$, for 150,250 , and $400 \mathrm{~g} / \mathrm{L} \mathrm{CrO}_{3}$, the voltages are, respectively, 5.2, 4.6, and 4.5 , and the throwing powers are $-50,-65$, and -85 per cent. Suppose, however, that instead of having a constant average current density, a fixed potential; for example, 5 volts, is applied. Then by graphic interpolation it may be seen that in the three solutions the throwing powers will be, respectively, about - 55 , -45 , and -40 per cent. Therefore, for a given voltage the more concentrated solution has a better throwing power. The best concentration will depend on the conditions and class of work. Owing to the larger loss by "drag out" of concentrated solutions, and to the higher voltage required for dilute solutions, an intermediate concentration of about $250 \mathrm{~g} / \mathrm{L}$ (33 oz./gal.) of chromic acid is generally suitable.

\section{(b) SULPHATE}

The actual content of sulphate is not so important as the ratio of chromic acid to sulphate. In this paper this ratio is expressed by weight; thus the statement " $\frac{\mathrm{CrO}_{3}}{\mathrm{SO}_{4}}=100 "$ means that the actual concentrations of chromic acid and sulphate (expressed in either $\mathrm{g} / \mathrm{L}$ or oz./gal.) are in the ratio of 100:1. In many other papers on chromium plating this ratio has been expressed in terms of the molarity of chromic acid and the normality of sulphuric acid, thus for the above ratio, $\frac{M \mathrm{CrO}_{3}}{N \mathrm{SO}_{4}}=50$. The latter ratio for any given solution is practically one-half that computed by weight.

Previous experiments have shown that the form in which the sulphate is added is immaterial. The concentrations of sulphate, $\mathrm{SO}_{4}$, given in this paper are for practical purposes the same as those of sulphuric acid, $\mathrm{H}_{2} \mathrm{SO}_{4}$, to be added. If other sulphates such as sodium or chromium sulphate are employed, chemically equivalent weights should be used.

As shown by comparison of Tables 2 and 3, a solution with the ratio of $\frac{\mathrm{CrO}_{3}}{\mathrm{SO}_{4}}=100$, which was found by Haring and Barrows to give the best average cathode efficiency, does not have as good throwing power as one with a smaller sulphate content; for example, 
$\frac{\mathrm{CrO}_{3}}{\mathrm{SO}_{4}}=200$. As shown in Figure 7, the improvement with the lower sulphate content is due to the fact that the cathode efficiency is thereby made greater at low current densities and less at high current densities. An increase in the sulphate content to make the ratio 50:1 greatly decreases throwing power. A smaller sulphate content than $200: 1$ is objectionable because brown streaks then form on the deposits. For practical purposes, the sulphate content should, therefore, be between 100:1 and 200:1, which latter ratio leads to slightly better throwing power. It was not found possible in these tests to detect effects due to small variations in the sulphate ratio, such as have been reported by Pinner and Baker from experiments with bent cathodes.

\section{(c) SOLUBLE ADDITIONS}

No attempt was made to study the effects of all the substances that have been suggested as additions to chromium-plating baths. The two selected were sodium dichromate and boric acid, for each of which definite claims have been made.

(1) Sodium dichromate.- The results in Table 4 show that the addition of a large amount of sodium dichromate ísolution 10) increases the throwing power from -65 per cent (experiment 17, Table 2) to -50 per cent (experiment 55, Table 4). That this slight increase in throwing power is due principally to an effective reduction in the sulphate ratio by the addition of the dichromate is shown by the fact that under these conditions a solution (No. 5) containing the same amount of free chromic acid, but less sulphate, has a throwing power of -52 per cent (experiment 34 , Table 3 ). If, however, the dichromate is added to a solution of low sulphate content (to produce solution No. 11), the throwing power is -100 per cent (experiment 57 , Table 4), which is much worse than that obtained without the dichromate. It seems, therefore, that any apparent advantage of the sodium dichromate can be more easily obtained by simply reducing: the sulphate content of the solution. Moreover the dichromate decreases the conductivity and for given conditions requires a slightly higher voltage ( 4.9 volts in experiment 55 , Table 4$)$ than the plain solution ( 4.7 volts in experiment 34 , Table 3$)$; while solution 6 , which contains $\mathrm{CrO}_{3}$ equivalent to both the $\mathrm{CrO}_{3}$ and $\mathrm{Na}_{2} \mathrm{Cr}_{2} \mathrm{O}_{7}$ present in solution 10 , requires only 4.4 volts and gives a throwing power of -62 per cent (experiment 49 , Table 3 ).

(2) Boric acid.-Concentrations of boric acid up to $0.25 \mathrm{M}(15 \mathrm{~g} / \mathrm{L}$ or $2 \mathrm{oz} . / \mathrm{gal}$.) have no appreciable effect upon the throwing nower.

\section{(d) TRIVALENT CHROMIUM}

The possible effects of trivalent chromium upon the throwing power are important, because this substance is always present in commercial plating baths and has sometimes been added intentionally.

The results in Table 5 and Figure 8 show that small concentrations of trivalent chromium have no measurable effect. When the $\mathrm{Cr}^{\mathrm{III}}$ is $0.05 \mathrm{~N}$; that is, exactly equivalent to the sulphate content, a condition that exists if chromium sulphate is used in preparing a new solution; the throwing power is practically the same as in the standard solution under the same conditions. Not until the concentration is greater than $0.5 \mathrm{~N}$ can any marked effect on throwing power 
be detected. High concentrations, such as 1.0 and $2.0 \mathrm{~N}$ (experiments 68 and 74, Table 5) lead to a definite improvement in throwing power, to -43 and -29 per cent, as compared with -65 per cent with the standard solution. This effect is undoubtedly due to the removal by the trivalent chromium of part of the free chromic acid to form chromium chromate. It may be significant that the throwing power with $2.5 \mathrm{M} \mathrm{CrO}_{3}$ and $1.0 \mathrm{~N} \mathrm{Cr}^{\mathrm{III}}$ is about the same $(-43$ per cent) as with 1.5 $M \mathrm{CrO}_{3}$ alone ( -50 per cent), (experiment 16, Table 2). This ratio corresponds to the formation of $\mathrm{Cr}\left(\mathrm{HCrO}_{4}\right)_{3}$. As the former solution required 5.5 volts, and the latter 5.2 volts, it is evident that any improvement in throwing power brought about by the presence of a large amount of trivalent chromium, can be more easily obtained by using a more dilute solution without trivalent chromium. Moreover, as shown by Schneidewind ${ }^{9}$ trivalent chromium reduces the range within which bright deposits can be obtained, which observation was confirmed in these experiments. It is evident, therefore, that no real advantage is gained by adding trivalent chromium or by allowing it to reach a high concentration.

\section{(e) IRON}

Most chromium plating solutions are kept in steel tanks, which are slowly attacked, thus introducing small amounts of iron into the baths. If steel anodes are used, considerable iron may pass into solution. It has been generally recognized that a large content of this element is objectionable as it decreases the conductivity and the plating range. It has been claimed that small concentrations of iron are beneficial, and it is sometimes intentionally added; for example, in the form of iron chromate, or of iron chromite (the mineral chromite).

The data in Table 6 and Figure 9 show that iron behaves very similarly to trivalent chromium in these solutions. Small concentrations, either alone (experiments 83 and 84) or in the presence of trivalent chromium (experiment 100) have no beneficial effect on the throwing power. Larger amounts increase the throwing power, but not quite so much as do equivalent concentrations of trivalent chromium. It appears probable that the iron is present as a ferric chromate, the formation of which removes an equivalent amount of the free chromic acid. This is confirmed by the higher resistivity, which requires an increased voltage to produce a given current density. This increased voltage, and the fact that the bright plating range is decreased by the presence of the iron, show that the presence of large amounts of iron is undesirable. It was found in our tests that the rate of solution of the mineral chromite, even when finely divided, in warm chromic acid solutions, is very slow, and that even after several days contact with an excess of the mineral, only small amounts of trivalent chromium and iron are thus introduced into the solution.

\section{COMPOSITION AND CONDITION OF BASE METAL}

All of the experiments recorded in Tables 2 to 6 were made on polished steel cathodes. Steel was selected because it was not appreciably attacked by the chromic acid in the 30 -minute periods used

See footnote 3, p. 28. 
in most of the experiments. Hence, there was no iron dissolved from the back of the plates during the experiments, and accurate weighings were facilitated.

Early experiments with cold-rolled steel, which had a fairly bright surface, showed that it was difficult to obtain reproducible results for cathode efficiency or throwing power. When the cathodes were buffed to a uniformly bright surface the results were much more concordant. That the cathode efficiencies, especially at low current densities, are greatly affected by the condition of the surface is shown by an experiment not recorded in the tables. In this test sandblasted steel cathodes were used, and under standard conditions the cathode efficiencies were about 10 and 1 per cent, respectively, on the near and far plates, representing a throwing power of less than $-1,000$ per cent.

Undoubtedly these differences in cathode efficiency are associated with differences in hydrogen overvoltage on the surfaces. It is generally recognized that the hydrogen overvoltage is decreased by roughening the surface. This facilitates hydrogen evolution and thus reduces the cathode efficiency of chromium deposition. It is "therefore advantageous to deposit chromium on highly polished metal.

A few experiments were made on the influence of a brief preliminary reversal of current upon the throwing power with steel cathodes. No effect could be detected. It is at least probable that the beneficial effect sometimes obtained by reversing the current on steel just before plating with chromium is due to the cleaning action caused by the anodic treatment with chromic acid.

The data in Table 7 show that the cathode efficiency and throwing power are also affected by the composition of the base metal. The throwing power on steel and brass is slightly better than on copper and nickel. The differences are due almost entirely to the cathode efficiencies at the low current densities. While these differences in throwing power are not great, they are sufficiently definite to affect also the covering power to be discussed in the next section.

\section{BENT CATHODE TESTS}

It was found that under the conditions used by us, the extent of the covering by chromium on the bent cathodes was fairly reproducible. Except as otherwise noted, copper was used in the bent cathode tests, in order to intensify the contrast between the appearance of the base metal and the chromium. It was found impracticable to photograph satisfactorily these bent cathodes, owing to the reflections from the polished copper and chromium. Therefore, line drawings have been used in Figures 10 to 16 to illustrate the results.

Figure 10 shows that there is approximate parallelism between the throwing power as previously measured and the extent of covering. This relation was confirmed by applying to the bent cathodes two sets of conditions, each of which had yielded about the same throwing power. It was then found that the covering power was also practically the same under the two conditions.

The numerical values for throwing power, included with Figures 10 to 16 , are based on measurements with steel, on which as above noted and also illustrated in Figure 16, the throwing power was 
slightly better than on copper. Hence, these values do not exactly correspond with those for copper, of which the bent cathodes con-
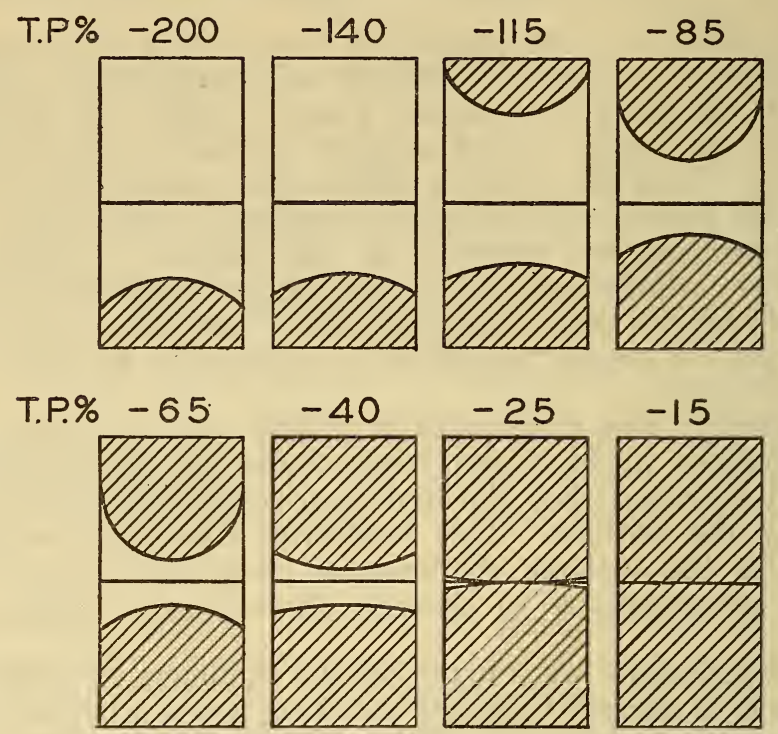

Figure 10.-Relation of throwing power (on steel) and covering power(on copper)

These and the following diagrams represent the appearance of cathodes bent at right angles when plated, and subsequently flattened out. The shaded portions are those covered with chromium.

sisted. As, however, all results for throwing power are only relative, the effects of different variables upon both the throwing power and covering power are illustrated by these diagrams.

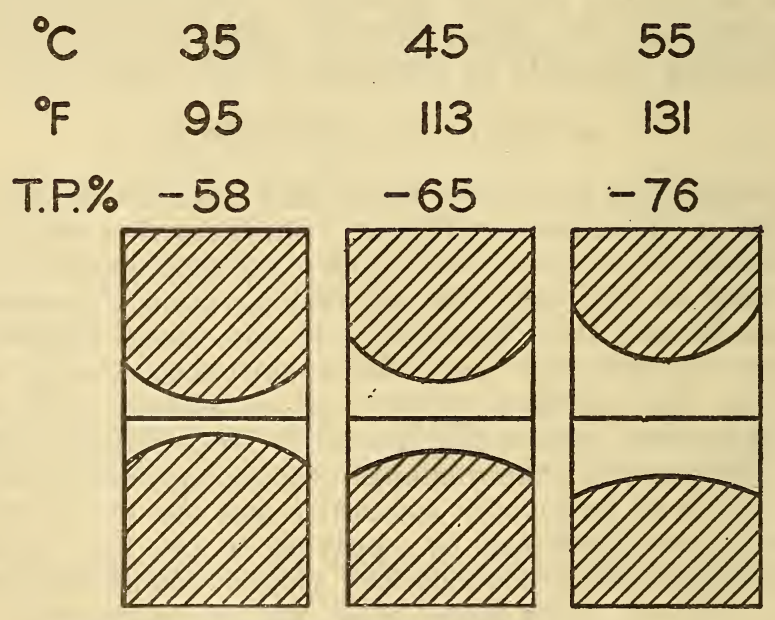

Figure 11.-Effect of temperature on covering power

Figures 11 and 12 show clearly that an increase in temperature lessens the covering power, while an increase in current density improves it. The effects of chromic acid, shown in Figure 13, are not 


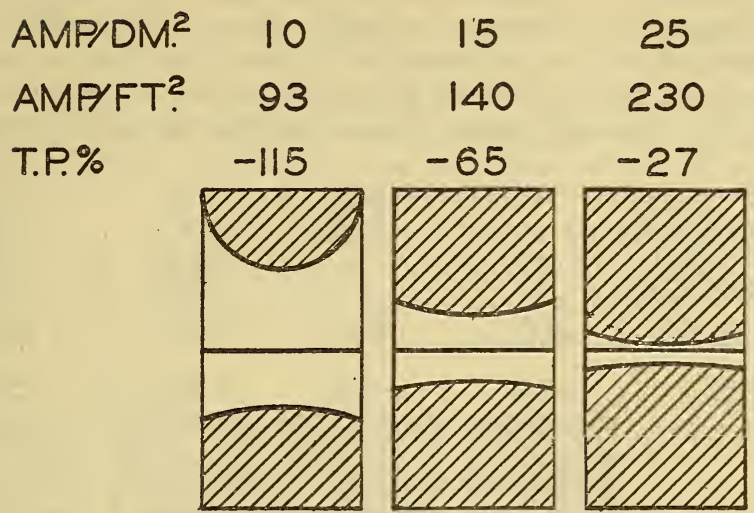

FIGURE 12.-Effect of current density on covering power

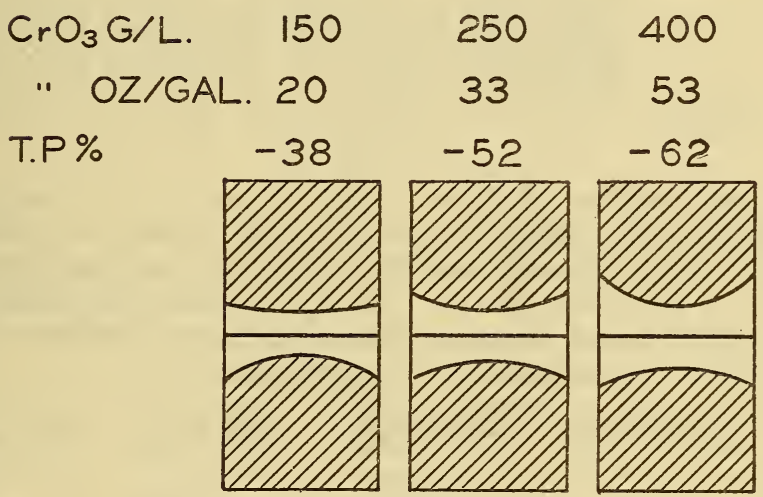

FIGURE 13.-Effect of chromic acid concentration on covering power

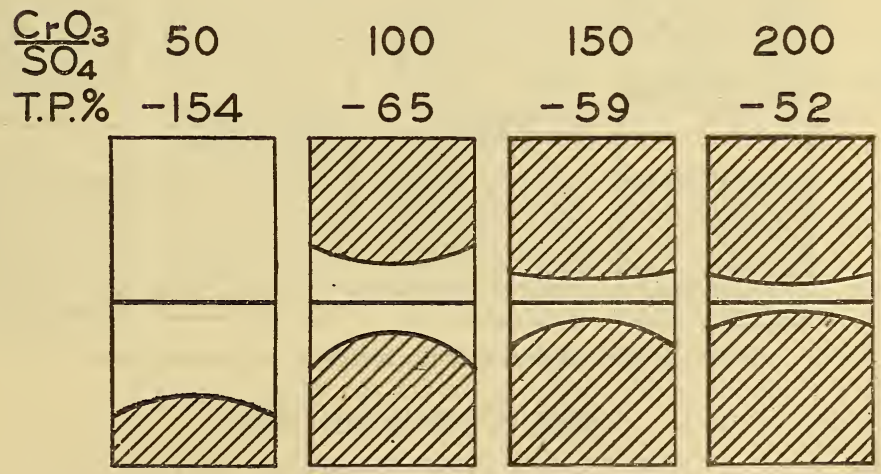

FIGURE 14.-Effect of sulphate concentration on covering power 
great but correspond approximately to the throwing powers. Similarly, in Figure 14, variations in sulphate ratio from 100 to 200 have only a small effect, but a ratio of 50 produces very poor covering. Figure 15 shows that trivalent chromium and iron have less beneficial effects on the covering power than upon the throwing power.

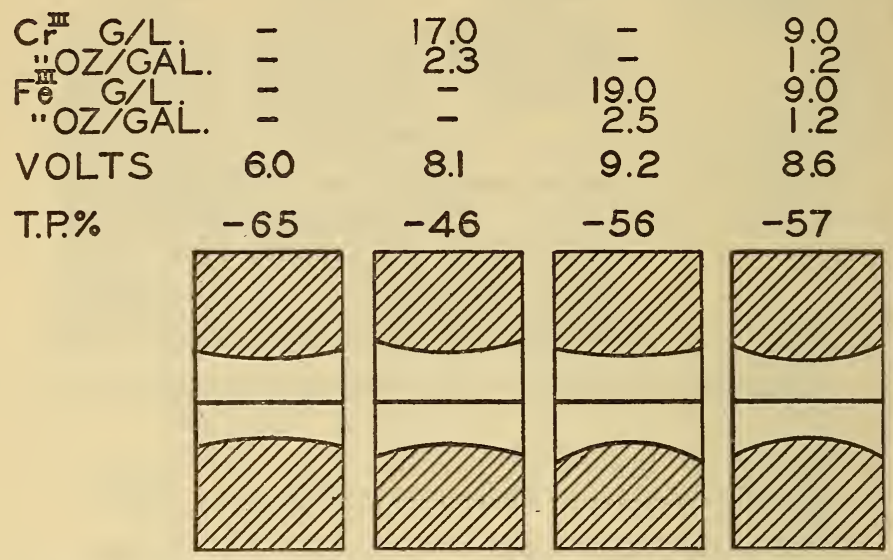

FiguRe 15.-Effect of trivalent chromium and iron on covering power

From these results, which are difficult to express quantitatively, it is evident that, in general, the covering power is parallel to the throwing power, although covering power does not portray small differences in throwing power. At least it may be safely concluded that the quantitative data on throwing power indicate the relative behavior under actual conditions of plating.

\section{COPPER BRASS STEEL NICKEL}
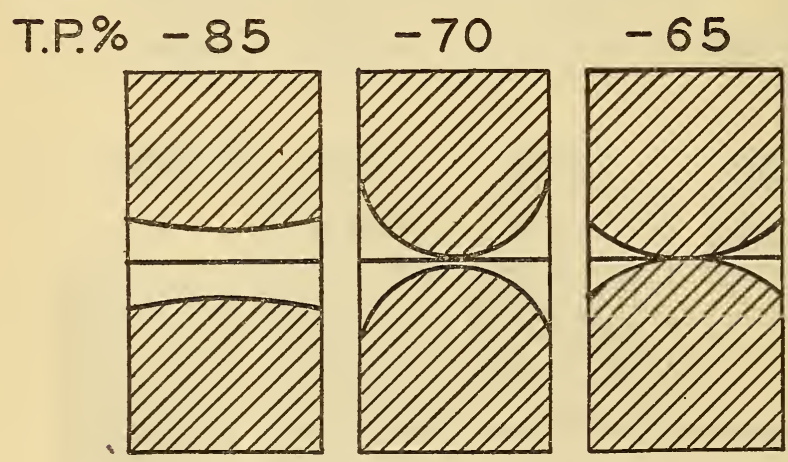

$-80$

FigURE 16.-Effect of base metal on covering power

\section{CONCLUSIONS}

1. Throwing power in chromium plating is determined almost entirely by the relative cathode efficiencies at the maximum and minimum current densities. An improvement in throwing power can be effected by any means which makes these efficiencies more nearly equal. 
2. An increase in temperature lowers the throwing power.

3. An increase in current density raises the throwing power.

4. By increasing both the temperature and the current density the throwing power is made greater than at lower temperatures and current densities. As the range of bright deposits is wider at high temperatures, these conditions are the most favorable. However, if the available voltage is limited to about 6 volts, an intermediate temperature and current density will yield best results.

5. For a given current density, better throwing power is obtained in dilute than in concentrated chromic acid solutions. If the available voltage is low, better throwing power is obtained in the more concentrated baths.

6. A ratio of $\frac{\mathrm{CrO}_{3}}{\mathrm{SO}_{4}}=200$ yields better throwing power than a ratio of 100 and very much better than a ratio of 50 .

7. Large additions of sodium dichromate to a solution with a sulphate ratio of 100 slightly increase the throwing power, probably by changing the effective sulphate ratio. If the latter is initially 200, sodium dichromate is detrimental.

8. Boric acid has no measurable effect on the throwing power.

9. Small concentrations of trivalent chromium have no effect. Large concentrations slightly improve the throwing power, making it equal to that in a more dilute solution. As the trivalent chromium reduces the conductivity and the plating range, it is not a desirable constituent.

10. Iron has almost exactly the same effects on throwing power as trivalent chromium, but has a greater detrimental effect on the conductivity and plating range.

11. The throwing power is much better on highly polished than on dull metal. On sand-blasted metal it is very poor.

12. The throwing power is slightly better on steel and brass than on copper and nickel.

13. The covering power as determined with a bent cathode is practically parallel to the measured throwing power.

14. The best throwing power ( -13 per cent) with bright deposits was obtained in a solution containing $250 \mathrm{~g} / \mathrm{L}$ (33 oz./gal.) of $\mathrm{CrO}_{3}$, $1.25 \mathrm{~g} / \mathrm{L}(0.17 \mathrm{oz} . / \mathrm{gal}$.$) of \mathrm{SO}_{4}$, at a temperature of $55^{\circ} \mathrm{C} .\left(131^{\circ} \mathrm{F}\right.$.) and an average current density of $35 \mathrm{amp} . / \mathrm{dm}^{2}$ (325 amp./ft. ${ }^{2}$ ). This required in the box, 6.4 volts. Such conditions are suggested for use when a voltage above 6 is available, and when the best attainable throwing power is desired.

15. When the voltage is limited to only 5 volts at the tank, a fair throwing power (about -60 per cent) can be obtained with $400 \mathrm{~g} / \mathrm{L}$ (55 oz./gal.) of $\mathrm{CrO}_{3}$ and $2 \mathrm{~g} / \mathrm{L}\left(0.27 \mathrm{oz}\right.$./gal.) of $\mathrm{SO}_{4}$, at a temperature of $45^{\circ} \mathrm{C}$. $\left(113^{\circ} \mathrm{F}\right.$.) and an average current density of $15 \mathrm{amp} . / \mathrm{dm} .^{2}$ (140 amp./ft. ${ }^{2}$ ).

16. In the latter solution, at a temperature of $35^{\circ}$ C. ( $95^{\circ}$ F.) and an average current density of $7.5 \mathrm{amp} . / \mathrm{dm}^{2}\left(70 \mathrm{amp} . / \mathrm{ft} .{ }^{2}\right)$ a throwing power of about -60 per cent is also obtained. This is usually satisfactory if the articles are not of very irregular shape or are favorably placed in the tank.

Washington, September 27, 1929. 